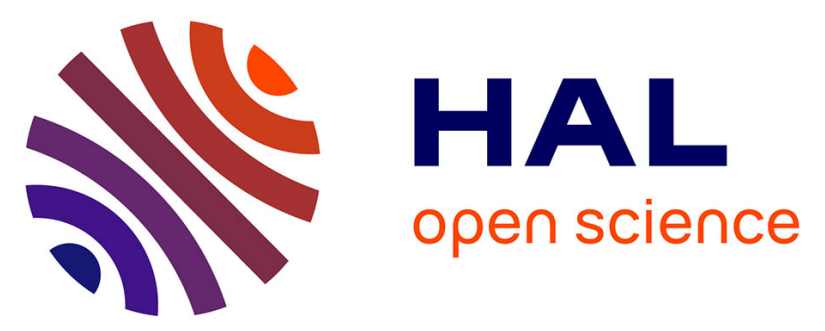

\title{
Upper mantle structure under the Zagros collision zone; insights from 3D teleseismic P-wave tomography
}

Mohammad Veisi, Farhad Sobouti, Sébastien Chevrot, Madjid Abbasi, Esmaeil Shabanian

\section{- To cite this version: \\ Mohammad Veisi, Farhad Sobouti, Sébastien Chevrot, Madjid Abbasi, Esmaeil Shabanian. Upper mantle structure under the Zagros collision zone; insights from 3D teleseismic P-wave tomography. Tectonophysics, 2021, 10.1016/j.tecto.2021.229106 . hal-03374771}

\section{HAL Id: hal-03374771 \\ https://hal.science/hal-03374771}

Submitted on 12 Oct 2021

HAL is a multi-disciplinary open access archive for the deposit and dissemination of scientific research documents, whether they are published or not. The documents may come from teaching and research institutions in France or abroad, or from public or private research centers.
L'archive ouverte pluridisciplinaire HAL, est destinée au dépôt et à la diffusion de documents scientifiques de niveau recherche, publiés ou non, émanant des établissements d'enseignement et de recherche français ou étrangers, des laboratoires publics ou privés. 


\section{Journal Pre-proof}

TEGTONOPHYSICS

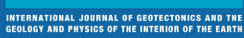

Upper mantle structure under the Zagros collision zone; insights from 3D teleseismic P-wave tomography

Mohammad Veisi, Farhad Sobouti, Sébastien Chevrot, Madjid Abbasi, Esmaeil Shabanian

PII: S0040-1951(21)00388-7

DOI: https://doi.org/10.1016/j.tecto.2021.229106

Reference:

TECTO 229106

To appear in:

Tectonophysics

Received date:

10 March 2021

Revised date:

10 September 2021

Accepted date:

5 October 2021

Please cite this article as: M. Veisi, F. Sobouti, S. Chevrot, et al., Upper mantle structure under the Zagros collision zone; insights from 3D teleseismic P-wave tomography, Tectonophysics (2021), https://doi.org/10.1016/j.tecto.2021.229106

This is a PDF file of an article that has undergone enhancements after acceptance, such as the addition of a cover page and metadata, and formatting for readability, but it is not yet the definitive version of record. This version will undergo additional copyediting, typesetting and review before it is published in its final form, but we are providing this version to give early visibility of the article. Please note that, during the production process, errors may be discovered which could affect the content, and all legal disclaimers that apply to the journal pertain.

(C) 2021 Published by Elsevier B.V. 


\title{
Upper mantle structure under the Zagros Collision Zone; Insights from 3D teleseismic P-wave tomography
}

\author{
Mohammad Veisi ${ }^{1}$, Farhad Sobouti ${ }^{1}$, Sébastien Chevrot $^{2}$, Madjid Abbasi ${ }^{3}$, Esmaeil Shabanian ${ }^{1}$ \\ ${ }^{1}$ Department of Earth Sciences, Institute for Advanced Studies in Basic Sciences (IASBS), Zanjan \\ Postal Code: 45137-66731, Iran. \\ ${ }^{2}$ GET, UMR 5563, Observatoire Midi Pyrénées, Université Paul Sc'u ${ }^{\dagger}{ }^{\prime}{ }_{1}$, CNRS, IRD, Toulouse, France. \\ ${ }^{3}$ Department of Surveying Engineering, University of Z nja ?, Zanjan, Iran
}

\begin{abstract}
We map the lateral va. ${ }^{\text {at. }}$ ns of P-wave velocity beneath the Zagros collision zone in Iran down to $800 \mathrm{~km}$ depth by $\mathrm{rt}_{\sigma_{1}}$ onal travel time tomography. We invert 32,293 relative travel time residuals from five temporary seismic networks across the collision zone in NW and central Zagros and northern Iran, and a large number of permanent stations distributed over the Iranian Plateau. A salient feature of our model is a $\sim 225 \mathrm{~km}$ thick lithosphere beneath the Zagros, almost twice as thick as in the rest of Iran. Slab detachment at a depth range of 250-300 km from the base of the subducted continental Arabia is clearly distinguishable in central Zagros. In NW Zagros detachment appears to be at an earlier stage. Beneath the central Iran Plateau, we observe
\end{abstract}


shallow low-velocity regions down to $200 \mathrm{~km}$ depth, and smaller patches with significantly higher velocity in the $200-400 \mathrm{~km}$ depth range. This pattern could suggest a post-collisional foundering of the mantle lithosphere in the upper plate. The subducted slab seems to penetrate into the lower mantle in a segmented fashion, with no evidence for a stagnant slab above the 660 $\mathrm{km}$ interface.

Keywords: Traveltime tomography; Zagros Mountains; Iranian Plateau; Continental collision; Slab detachment; Lithospheric delamination

\section{Introduction}

The Iranian Plateau has formed as a result of the ciosun of the Neo-Tethys Ocean and the Arabia-Eurasia continental collision. Some of $t^{1} \geq$ mue recent estimates put the onset of collision in the Oligocene (Egan et al., 2009; $\underline{\text { Agara }}+$ al., 2011; McQuarrie and van Hinsbergen, 2013; Pirouz et al., 2017). The Zagros Mol..211. on the southwestern margins of the plateau are the current locus of the collision in Ir: ( Fig. 1), accommodating a third of the total convergence of the Arabian platform under ce trai Iran. The Main Zagros Thrust (MZT), the surface expression of the intracontinental s ıtur (e.g., Stöcklin, 1968; Paul et al., 2006 and 2010), defines the northeast boundary of the Zagros range. Coeval with the deformation of the Zagros, mountain building processes and volcanism have been active in the Alborz Mountains in the north (e.g.,

Guest et al., 2006 and 2007; Ballato et al. 2010), while central Iran has experienced relatively recent plateau formation (5-10 Ma) and post-collisional volcanism (Omrani et al. 2008; Hatzfeld and Molnar, 2010; Chiu et al. 2013).

A thorough understanding of the Zagros collision zone and its Late Cenozoic history requires detailed tomographic images of upper mantle structures. Several questions, in particular, are 
important in this regard; (1) What is the amount of lithospheric thickening since the onset of collision (2) Has this lithospheric thickening been limited to the margins of the upper plate, or did it propagate far into the plate interior in central Iran? (3) Has the collision resulted in an effective detachment of the oceanic slab from the underthrusting Arabian continental margin? (4) If the Iranian Plateau is the result of a late-stage lithospheric foundering/delamination, then, is there any evidence of that process left anywhere in the upper mantle?

Many body and surface wave tomographic studies from the glr oat scale (e.g., Van der Meer et $\underline{\text { al., 2018) }}$ to the regional scale (e.g., Chang et al., 2010; K( 11ak ov, 2011, Maggi and Priestley, 2005; Al-Lazki et al., 2004) have mapped the upper $n$ ani: seismic velocities and revealed the large-scale structure of the Tethyan subduction $7 m$ me bentath the Zagros and Iranian Plateau. These studies have consistently found a high $v^{\prime}$ 'city and thick lithosphere beneath the Zagros, whereas central Iran is characterized by a low velocity and thin lithosphere.

Local 2-D tomographic imaging of Ira 1 vas first performed by Kaviani et al. (2007) and many other studies have followed sir'e (c.g., Paul et al., 2010; Motaghi et al., 2012; Rahmani et al.,

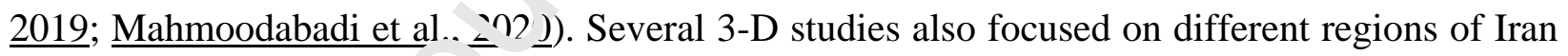
(e.g., Shomali et al., $\left\llcorner^{? 1} \perp\right.$, Shad Manaman et al., 2011; Mahmoodabdi et al., 2019). These previous studies, which suffered from a rather limited station coverage, have confirmed the geometry of the underthrusted Arabian margin beneath central Iran and of the subducted oceanic slab. However, the available global tomographic models have poor resolution in the shallow upper mantle beneath Iran, mainly because of their coarse spatial discretization. On the other hand, regional-scale 2-D models, owing to their limited aperture $(<600 \mathrm{~km})$, have a poor resolution at depth, in particular in the mantle transition zone. In this study, we combine several datasets from permanent and temporary seismic networks installed in Iran to improve both the 
aperture and ray coverage. The new extended dataset allows us to significantly improve the spatial resolution in both the shallow and deep parts of the mantle, providing key insights into the interaction of the two converging plates in the subduction zone and the fate of the subducted slab.

\section{Data}

Our dataset consists of teleseismic P-wave arrival times from 202 -mporary, and 102 permanent stations in Iran (Fig. 1 and Table 1). The temporary stations belc $\urcorner$ o o several arrays deployed at different times in various parts of the collision zone. The 'agıus01 and Zagros03 arrays consist of two transects deployed in central and western Zagice or a few months in 2001 and 2003 respectively. The CIGSIP array operated for one $\mathrm{v}$-a) (2013-2014) along three parallel lines in western Iran covering the Zagros and $\mathrm{Al}^{1}$ orz mountains. The IASBS-CAM-1 (2008-2012) and IASBS-CAM-2 (2014-2016) arrays we` installed in NW Iran and western Alborz, respectively, and operated for 6 to 30 months. We ls s use the data of the permanent stations of the Iranian national networks IRSC and IN ' $N$ rcoorded between 2012 and 2019 to increase the resolution of our output model in the regi $\urcorner \mathrm{s}$ jetween the temporary arrays. With this distribution of seismic stations our tomograph sudy covers a significant part of the collision zone: NW and central Zagros, western and central Alborz, and a significant part of central Iran.

\section{Data preparation and inversion method}

We picked 32,293 first P-wave arrival times from 1588 teleseismic events with magnitudes greater than 5.5 and epicentral distances between $28^{\circ}$ and $95^{\circ}$ (Fig. 2a). For picking the relative $\mathrm{P}$ travel times we used the method developed by Chevrot (2002). The advantage of this method is that we can obtain robust and accurate travel time measurements even on very noisy data. The 
travel times need to be corrected for crustal thickness, station elevation, and ellipticity of the Earth. For crustal thickness correction, we used the Moho depth map from Kaviani et al. (2020). We improved that map by including new crustal thicknesses estimated from P-wave receiver functions obtained from the temporary stations. We gridded the surface of the model with $15 \times 15$ km blocks. Inside each block, we determined the crustal thickness by interpolating from the nearest points available from the receiver functions and the Moho map. The station elevation corrections were calculated by computing the travel times betwee. the surface of the WGS 84 ellipsoid and the station elevations. We also corrected the tr Earth. We then computed average event travel times tha were removed from the travel time residuals. These relative P-wave travel times were then 1 . verted following the method of Aki et al. (1977), known as the ACH method.

Model parameterization in any inversion mu ${ }^{*}$ follow some rules. The cell size in the uppermost layer of the model should not be srial $a r$ han the smallest distance between the stations, the depth to the bottom of the model : houid be no more than $2 / 3$ of the largest station distances, and the cells should be large enous $h$ to contain sufficient ray crossings to prevent smearing in the output model (Evans anc Aci auer, 1993). We found that the choice of 25-km cubic cells was a good compromise and $\mathrm{n}$ model has been parameterized with 33 layers from the surface down to $825 \mathrm{~km}$ depth.

We added damping and smoothing constraints to regularize the inversion. The tomographic model is given by the solution of

$$
J^{T} W_{o b s} \delta \Delta t=\left(J^{T} W_{o b s} J+W_{d a m p}+W_{\text {smooth }}\right) \Delta m, \quad \text { Equation } 1
$$


where $\delta \Delta t$ is the vector of relative traveltimes, $J$ is the Jacobian matrix, $W_{o b s}$ is the weight matrix of the observations, $W_{\text {damp }}$ is the damping matrix, $W_{\text {smooth }}$ is the smoothing matrix and $\Delta m$ is the vector of velocity perturbations. The Jacobian matrix for each event is given by

$J_{i j}=\left(G_{i j}-\bar{G}_{i j}\right)$

Equation 2

where each element of $G_{i j}$ is the travel time of the $i$ th ray in the ${ }_{\text {ith }}$ cell, and the elements of $\bar{G}_{i j}$ are the averages of $G_{i j}$ over all the stations that have recc.ui 1 uie event. Each element of the Jacobian is the travel time of the $i$ th ray in the $j$ th cell frr $\cdots w$ hich the mean travel time of all rays of the event passing through the cell is subtracted. Tr $\_$cu cept behind this modification is that $\bar{G}_{i j} \Delta m$ is equivalent to the mean travel time if cun event, therefore, the modified Jacobian matrix has the effect of removing the avera $\rightarrow$ ray contribution. This eliminates the necessity for arbitrarily choosing one mean velocit; as , reference. Recently, Maupin (2020) has shown that using demeaned event sensitivity ren. als also removes the long wavelength biases arising from asynchronous station deployni $\eta$ ts. Therefore, our inversion scheme is well adapted to the joint inversion of travel time data coming from different permanent and temporary sub-arrays that may not have recorded the same number of events.

We regularize the inversion by adding damping and smoothing constraints. To smooth the solution, we damp the norm of the Laplacian of the model. The procedure for finding the optimum damping and smoothing coefficients is as follows. 1) We start the tomography with two initial damping and smoothing factors. 2) We run the inversion code iteratively inside two loops. The outer loop consists of 10 iterations over the damping factor, and the inner loop consists of 20 iterations over the smoothing factor. In this step $10 \mathrm{~L}$-curves, one for each damping factor are 
produced (see Figure S1 for selected L-curve). 3) We repeat steps 1 and 2 four times with different initial factors and increments to ensure that the best initial values are found. We pick the best L-curve from a set of 40 . To choose the best damping and smoothing factors, we impose a RMS reduction of at least 50 percent, and a smooth final model not dominated by small-scale anomalies. The inversion achieved a final RMS reduction of 56.8\%. The LSQR (Least Squares using the QR factorization) method of Paige and Saunders (1982) was used to solve the equations. This method is very fast and employs sparse matrix techiti iues.

We performed a synthetic checkerboard test to identify th $\Rightarrow$ p rts of the model that are well resolved and to determine the amount of vertical smea ing in regions of low ray density. In this test, the same complete ray distribution as in $\cdots \cdot \cdots$ real ciataset has been used. The starting synthetic velocity model is made of $75-\mathrm{km} \sim \mathrm{ul}: \mathrm{c}$ velocity anomalies organized in 3 horizontal layers in the shallow part of the model $(<45 \iota \mathrm{km})$ and 2 layers of 100-km cubic anomalies in the deeper parts. The input velocity ano $n^{\prime}{ }^{\prime}$ ies had $\pm 5 \%$ perturbations. The synthetic blocks were placed at 50-125 km, 200-275 ki . 3 J J-425 km, 500-600 km, and 675-775 km depth. We also added $10 \%$ random noise to the synthetic relative residuals. The synthetic test achieved an RMS reduction of $62 \%$. Fig 3 hov s the results of the test in layers $4,10,16,23$, and 30 of the model. In the shallow parts of the model (i.e., layer 4) the velocity variations are best resolved in regions of good station coverage. In the mid-upper mantle depths (i.e., layers 10 and 16) where ray crossing reaches its maximum, good resolving power is achieved in many parts of the model. In the deeper parts (i.e., layers 23 and 30), the ray density is distributed more evenly among the cells, and thus the inversion returns a more uniform pattern of velocity anomalies. Fig. 4 shows the results of the synthetic test along 7 cross-sections from northwest to southeast. In general, the resolution is good in the upper $400 \mathrm{~km}$. In the regions far from the temporary arrays (e.g., 
sections $\mathrm{d}, \mathrm{e}$, and f) the near-surface anomalies show somewhat lower amplitudes with respect to the deeper features. Beneath the CIGSIP array and neighboring regions (section b), the resolution is good from the top to the bottom of the model. However, vertical smearing in the lower half of the model becomes significant in the northwestern part of the model (sections a, b and c).

\section{Tomographic Results}

Fig. $2 \mathrm{~b}$ shows the average station residuals. Stations in the Zagros Mountains and the SanandajSirjan Zone (SSZ) are characterized by negative residuals the most pronounced negative residuals are observed in NW Zagros. Positive residuals a e ouserved in central Iran (including the UDMA), the Alborz Mountains, and NW Iran. A: $\urcorner n_{0}$ the margins of the South Caspian Basin, the residuals are mostly negative.

Fig. 5 shows 12 horizontal plots of the ve city anomalies between 25 and $825 \mathrm{~km}$ depth. At shallow depths, the resolving powe ot the inversion is limited owing to the sub-vertical incidence of teleseismic P waves Thi 25-50 km depth (Fig. 5a) corresponds to the lower crust throughout most of Iran. At thi a pth, the NW and central Zagros, and to some extent the SSZ, are characterized by high ver cities, but in the middle part of the model, the high-velocities are limited to the Zagros anc do not extend into the SSZ. Central Iran and the Alborz (with the exception of Caspian coastal areas) are characterized by low velocities in the lower crust. In the depth range corresponding to the lower lithosphere $(75-175 \mathrm{~km})$ the Zagros and the SSZ are again dominated by high-velocity anomalies, whereas in central Iran and central Alborz low velocities are observed. This suggests a strong and thick mantle root beneath the Zagros and a thinner lithosphere beneath central Iran. Between 200 and $325 \mathrm{~km}$ depth, the Zagros highvelocity anomalies gradually shift northeast across the boundary with central Iran, suggesting the 
presence of a north-dipping lithospheric structure beneath the suture zone. In central Iran, a broad zone of high velocity appears between NW Zagros and Alborz. In the 375-825 km depth range, the most pronounced feature of the model is a broad high-velocity anomaly located beneath the SSZ and central Iran, whereas low velocities are observed beneath the Zagros.

Figures 6 and 7 show vertical sections across the tomographic model along 8 profiles. These profiles are ordered from northwest to southeast, with the distanse axis origin set at the MZT. The velocity perturbations in most of the profiles are characteri ed iy 4 major anomalous zones. The first anomaly, marked as ALH (Arabian Lithosphere Hi६ $\urcorner$ ) is a shallow high-velocity feature beneath the Zagros and SSZ extending down to a der $\mathrm{h}$, f about 270-300 km. It also extends beneath central Iran by as much as $75 \mathrm{~km}$ north of tha MZ1 (see also Fig. 5d). In the eastern half of the model, the anomaly is poorly resolver at hallower depth where station coverage is sparse (e.g., Fig. $7 b$ and c). We interpret the AL 4 anomaly as the Arabian margin underthrusted beneath central Iran. The second ar of ' aly marked as TSH (Tethyan Slab High), is a highvelocity region located north of the iNZT under SSZ and central Iran. In most of the cross sections it is located below 40 $\mathrm{kn}$ depth and extends to the bottom of the upper mantle, but in NW, as well as SE (Fig. ik a ld l) it penetrates into the lower mantle as well. The resolution test (e.g., Fig. 4b-e) indicat $\sim$ chat these features in the upper mantle are well resolved. We interpret the high-velocity TSH as the subducted Neotethyan slab. The third anomaly, marked as $\mathrm{CIH}$ (Central Iran High), is a high-velocity body beneath central Iran, observed at $200 \mathrm{~km}$ depth in the western part of the model. Towards the eastern regions and beneath central and eastern Alborz it gradually deepens to about $450 \mathrm{~km}$ depth (Fig. 7c). In the northern end of the profiles crossing the Alborz (e.g., Fig. 6a and b), a high-velocity shallow zone characterizes the transition between the Alborz Mountains and the South Caspian Basin, which suggests that the nature of the 
Caspian lithosphere is different from the continental regions surrounding it. The fourth major anomalous zone in the model is the shallow low-velocity anomaly CIL (Central Iran Low) beneath central Iran and the Alborz. This anomaly is confined to the upper 150-200 km and reveals a thinner central Iran lithosphere bounded by the thick Zagros and South Caspian lithospheres.

\section{Discussion}

Seismic velocities in the Earth are influenced by temperature. al ala ticity, partial melting, water content, and rock composition. Although the effect of anc astıuty and rock composition can be largely ignored in the upper mantle where the oceanic cl.o is descending (Goes et al., 2000), isolating their relative contribution to the veloc to $f$ eld is challenging. In the following, we therefore assume that velocity perturbatior $s \mathrm{~m}$.inly result from temperature anomalies.

Several scenarios have been proposed $\therefore \mathrm{e}_{\lambda_{1}}$ lain the geodynamic evolution of the Arabia-Eurasia plate system. Among them, models su.ggested by Dercourt et al. (1993) and Sengör and Natal'in

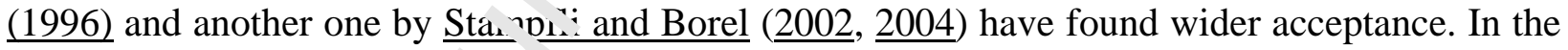
first model, except for a she r-lived intra-oceanic subduction near the southern margin of the Neo-Tethys that resulted i 1 the emplacement of the Oman ophiolites on the Arabian margin, all of the subduction has taken place at the northern margin of Neo-Tethys beneath Anatolia and central Iran. In the model proposed by_Stampfli and Borel (2004) the subduction of the NeoTethys ridge beneath the Iranian blocks (Lut and SSZ) in the Mesozoic was followed by the opening of an intra-oceanic back-arc basin east of Arabia (the so-called Semail Ocean). During the Cenozoic, the Semail Ocean subducted beneath Eurasia. Hafkenscheid et al. (2006) used the above models to predict the present positions of Neo-Tethyan lithospheric domains subducted 
since the Mesozoic. They compared their predictions with results from global mantle P-wave tomographies and concluded that most of the subducted Neo-Tethyan lithosphere is presently residing in the lower mantle between 800 and $2000 \mathrm{~km}$ depth. They further argued for the occurrence of an Early Oligocene slab detachment under the northern Zagros suture zone. According to this reconstruction, the high-velocity bodies presently observed in the mantle transition zone are mainly the Arabian margin lithosphere that has been pushed down since the Oligocene break-off and during the course of continental collision. ¿ gard et al. (2011) presented a synthesis of various geological data to reconstruct the $f_{0} f_{1} \ldots$ ation history in the Zagros collision zone from $150 \mathrm{Ma}$ to present. Their reconstr ation is broadly similar to that of Hafkenscheid et al. (2006). They outlined a major slab b. ak-off episode in Late Paleocene, and a more recent partial slab tear during the Miocere $(-10 \mathrm{Ma}$ ) based on adakite formation in parts of the UDMA in central Iran (Omrani et ai $\left.\underline{2}^{r}, \underline{08}\right)$.

\section{The structure of the Zagros lithosph're}

Our model shows high velociti $s$ in the Zagros lithosphere and low velocities north of MZT in central Iran. A similar struc 'Ir: has been mapped in previous studies (e.g., Asudeh, 1982; Bijwaard et al., 1998; k. vlaul et al., 2007; Shomali et al., 2011; Koulakov, 2011; Priestley et al., 2012; Mahmoodabadi et al., 2019). We interpret these anomalies as evidence for a colder and thicker lithosphere beneath the Zagros versus a thinner and warmer lithosphere in the surrounding regions. Priestley et al. (2012) used temperature modeling to derive the depth of the lithosphere-asthenosphere boundary from shear wave velocity profiles. They obtained a value of $\sim 120 \mathrm{~km}$ for the thickness of the lithosphere everywhere except in the Zagros, for which their estimate was twice as much. Priestley et al. (2012) argued that the thickening of the Zagros lithosphere results from shortening. Motaghi et al. (2017a, $\underline{b})$ inverted receiver functions from 
seismic profiles in western and southern Zagros to derive shear wave velocity profiles, from which they inferred a deep LAB and thick lithosphere beneath the Zagros and SSZ (> $200 \mathrm{~km}$ ). They interpreted this thickening as resulting from the underthrusting of the Arabian lithosphere beneath central Iran. Mohammadi et al. (2013) used P-to-S and S-to-P converted phases to constrain LAB depths of 130 and $150 \mathrm{~km}$ beneath western Zagros and SSZ, respectively, and significantly shallower depths of $80-90 \mathrm{~km}$ in central Iran and the Alborz. They also mapped a sharp lithospheric thickness variation between the SSZ and UDMA in central Iran. The P-wave

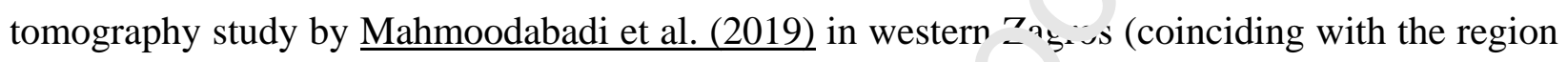

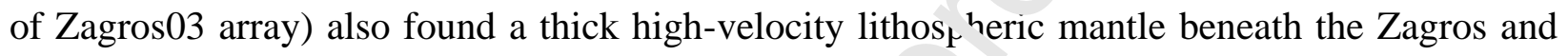
low-velocities beneath central Iran and Alborz.

The 2-D P-wave tomography of Rahmani $\mathrm{e}_{-}^{+}$I. (2019) along the CIGSIP profile in NW Zagros showed a low-velocity wedge at a depth of ${ }^{150} \mathrm{~km}$ near the frontal edge of the Arabian plate beneath the suture zone. They interpr ${ }_{-1 t}{ }^{A}$ it as the beginning of the detachment of the lower part of the Arabian lithosphere from $\mathrm{s}$ upper part. The profile of Rahmani et al. (2019) coincides with our cross-section in Fig. 6 c. We also identify a very thick lithosphere in the Zagros (anomaly ALH), but ou $\cdot m_{1}$ del does not support a detachment of the Arabian lithosphere.

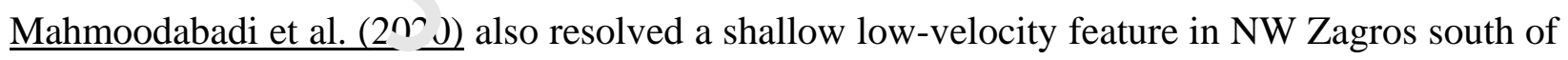
the SSZ, and explained it as a narrow low-velocity corridor formed as a consequence of delamination of the Arabian lithosphere. In general, we observe a thick lithosphere along the strike of the Zagros throughout the range (e.g., Fig. 5b, c). However, important variations in the geometry of the frontal edge of the advancing Arabian plate are observed from NW to SE. In NW Zagros, the Arabian lithosphere achieves a maximum of $120 \mathrm{~km}$ of underthrusting beneath the SSZ at the location of the Zagros03 seismic line (Fig. 5d). In contrast, in central Zagros 
(southeast of Zagros03 line in Fig 5) our model resolves low-amplitude velocity anomalies on both sides of the suture zone, with no clear evidence for significant underthrusting beneath central Iran. In SE Zagros, Motaghi et al. (2017b) observed evidence for lithospheric buckling with no indication of significant underthrusting of the Arabian lithosphere beneath central Iran. They argued that the abnormal thickness of the lithosphere could be the result of internal deformation of the Arabian lithosphere as it collides against the relatively strong central Iran lithosphere. Several previous tomographic studies have reporit' a similar non-cylindrical structure of the Zagros lithosphere along the collision zone. The 5 and S-wave imaging of the upper mantle in Iran by Alinaghi et al. (2007) and Koulak_v (2011) show that central Zagros is underlain by a low velocity anomaly in the shallow un . mantle that is not observed beneath NW and SE Zagros, in good agreement with $\underline{\mathrm{Ch}} \underline{n}_{i}$ et $\underline{\underline{11} .(2010)}$ and Priestley et al. (2012).

\section{The structure of the subducted slab}

A prominent feature of our tomograr hi : model is the combined ALH + TSH high-velocity region beneath the collision zc: e thist extends from the surface down to the transition zone. In the southeastern part of the si 'd region, it penetrates the lower mantle. The apparent dip of the structure is about $60^{\circ}-n^{\prime}$ wwards northeast throughout the collision front. We interpret this structure as the underthrusting Arabian margin, still partially connected to the last fragments of the subducted oceanic slab, with a detachment around 200-300 km depth. The degree of detachment varies along the collision zone; whereas slab detachment seems to have remained at an early stage beneath NW Zagros, it seems more mature beneath central Zagros. The depth of detachment is just beneath the thickened Arabian lithosphere, and since the top of the detached slab is still observed at a shallow level, it might be a relatively recent event developed in the latter stages of collision. Omrani et al. (2008) documented a post-Late Miocene formation of 
volcanic rocks with adakitic signature in UDMA in central Iran, and based on their spatially limited distribution along the arc, they inferred that they must have formed as a result of slab melting during a slab break-off event. Agard et al. (2011) expanded on this idea and used other geological evidence to suggest that a late partial break-off/tear caused the detachment of the Neo-Tethyan slab from the continental lithosphere at around $10 \mathrm{Ma}$. They also argued that the extent of break-off must be greater in central Zagros than in the northwest. A number of previous tomographic studies have provided evidence for slab detachment in the Zagros. Van der Meer et al. (2018) showed a tomographic image beneath northern Zac, $\cdots$ s.....ere a detached slab segment with its top just below the Zagros root descends into tha lower mantle. In western Zagros, Mahmoodabadi et al. (2019) evidenced a high-velocitv . . omaly at $300 \mathrm{~km}$ depth disconnected from the Zagros lithosphere. They interpreted $i^{+} c^{\prime}$ a iemnant of the Neo-Tethyan oceanic slab detached from the leading continental edg . F.ahmani et al. (2019) in their tomography study on the CIGSIP array obtained a similar imare. They found a pronounced high-velocity anomaly at depths greater than $350 \mathrm{~km}$ north $\mathrm{c}^{\mathrm{f}}$ the 7 agros suture and interpreted it as a remnant of the NeoTethyan slab. However, their amographic model does not show a separation between the continental lithosphere at the wace and the remnant slab at depth. They performed a synthetic modeling and showed thi. the apparent continuity between the two high-velocity regions could be the result of smearing. Nevertheless, they stopped short of explicitly arguing for a slab detachment event.

The available evidence from seismic anisotropy is in good agreement with a slab detachment event beneath the Zagros, as well as to the generally-complex lithospheric thickness variations between the Zagros and central Iran as discussed in the previous section. Recent shear wave splitting studies by Sadeghi-Bagherabadi et al. (2018), Kaviani et al. (2021) and Arvin et al. 
(2021) have revealed a complex mantle flow pattern beneath Iran compared to a simpler flow regime beneath the Anatolian Plateau and Arabian Plate, where lithospheric thickness varies relatively smoothly. Kaviani et al. (2021) hypothesized that the southwest mantle flow field is deflected beneath the Zagros by the lithospheric keel, producing a NW-SE toroidal flow beneath central Iran parallel to the strike of the collision zone. Similarly, Sadeghi-Bagherabadi et al. (2018) invoked a combination of the Zagros keel effect and an asthenospheric edge-driven convective flow beneath central Iran to explain the NW-SE fast ${ }_{\mathrm{s}_{1}}$ litting directions under the southwestern margin of central Iran. In NW Iran and the Alr - . sion where the lithosphere is thinner, the anisotropic fast-axis directions suggest a $\operatorname{sim}_{\mathrm{r}}{ }^{1} \mathrm{e}$ mantle flow field away from the collision zone. The inferred circular pattern around the $<$; ros keel implies sharp boundaries for the Zagros lithosphere, in good agreement with o tr mography results. It also implies a gap in the slab to explain the mantle flow trans ${ }^{2} r+\jmath$ central Iran. This gap may have result from the slab detachment event. The proposed i ael deflection and associated circular flow is mainly concentrated in NW and South evidenced slab detachments (i.t. proiiles CR6 to CR12, and CR37 and region to its SE in Fig.6 and 7). The evidence from $e_{1}{ }{ }_{1} \mathrm{c}$ anisotropy corroborates our evidence for slab detachment and furthermore, it indicates that the zone of detachment possibly has a significant role in the organization of the mantle flow field beneath the collision zone.

Most cross sections in NW Zagros image a Tethyan slab descending into the lower mantle directly. This feature is not as clear in the southern part of the model (e.g. profile CR37 in Fig.7). Kaviani et al. (2018) studied the variations of the mantle transition zone thickness beneath the Middle East. They identified a significant depression of the 660 boundary and a modest uplift of the 410 in NW Zagros, corresponding to our western profiles. They interpreted this feature as 
resulting from the presence of a slab segment in western Zagros. In south central Zagros they observed the uplift of both 410 and 660 discontinuities, which precludes the presence of stagnant slab in that part of the mantle.

To evaluate the reliability of our tomographic model and assess the amount of smearing that may mask the distances between the prominent anomalous regions, we performed additional synthetic resolution experiments to test if the major anomalies observed in our tomographic model are adequately resolved. Specifically, we modelled the ALH, TSH, ${ }_{n}$ na $\mathrm{ClH}$ anomalies in the region encompassing the CIGSIP and Zagros03 arrays where ther is jood station coverage and raycrossing density. Fig. 8 shows the results of the synt iet ' test. The real-data anomalies were modelled by uniform horizontal prisms placed acrsas the western part of the model. The ALH anomaly had a polygonal shape with its base $n t: 10 \mathrm{~km}$ depth. The TSH and CIH had rectangular sections. We varied the position of the top o. the TSH prism, from $25 \mathrm{~km}$ to $175 \mathrm{~km}$ below the base of ALH. Fig. 8 illustrates the ey ce + of vertical smearing in our inversions. In the 200-400 depth range, where ray crossing maximum, horizontal boundaries have been displaced by as much as $50 \mathrm{~km}$ along the vertic. 1 cirection. Vertical boundaries are much better resolved. In one model run we assumed ai unt roken slab down to $650 \mathrm{~km}$ depth (Fig. 8d). The inversion returned a continuous unbroken hir $\mathrm{n}$-velocity region from surface to bottom, a very different pattern from what is observed in the real-data tomography. Anomalous bodies vertically separated by more than $100 \mathrm{~km}$ can be resolved. We also observe that the geometry of the resolved synthetic anomalies changes by only a moderate amount between the various cross-sections. Overall, the structures beneath profiles CR 9 to 14 are the best resolved.

van Hunen and Allen (2011) quantitatively investigated slab break-off subsequent to continental subduction. They found that the mechanical strength of the slab has a major role in the timing of 
slab break-off after the onset of collision. For an old and strong subducting slab this time is 20$25 \mathrm{Ma}$, while for a young and weak slab it can be as early as $10 \mathrm{Ma}$. van Hunen and Allen (2011) applied their findings to the Arabia-Eurasia collision zone by assuming an age of $35 \mathrm{Ma}$ for the initial collision and a Permian age of 200 Ma for the subducting Neo-Tethyan slab. They deduced that slab break-off could not have occurred before 15-10 Ma. Better estimates now put the onset of collision in the Zagros at around 27-25 Ma (Egan et al., 2009; Agard et al., 2011 and references therein). Following van Hunen and Allen (2011), slab de ‘ chment in the Zagros could have occurred as recently as $5 \mathrm{Ma}$ ago, significantly more cainly than what the geological evidence suggests. This discrepancy can be resolved by a $a_{\sim}$ uming that the subducting slab was weaker than what is expected for its age. One can also a $a_{\llcorner}$ue that the actual slab break-off in the Zagros has been a faster process. In fact, nume : $\mathrm{a}^{1}$ modeling by Duretz et al. $(\underline{2011}, \underline{2012})$ incorporating a combination of viscous $a \cdot d$ J eierls creep mechanisms predicted that an $80 \mathrm{Ma}$ old oceanic lithosphere subducting at a rate of $5 \mathrm{~cm} / \mathrm{yr}$ can break off significantly sooner, at about $11 \mathrm{Ma}$ after the onset of $\mathrm{co}^{11:}$ : sic $\mathrm{n}$ and at a depth of about $300 \mathrm{~km}$. In terms of time and depth of break-off, the predictic.'s by Duretz et al. $(\underline{2011}, \underline{2012})$ are in good agreement with the available geological evidenne $r$ d our tomography results in the Zagros. Since our tomographic images evidence a break $\cdot f t$ developed unevenly along the collision zone, this would suggest that the process is still ongoing.

\section{The upper mantle structure beneath central Iran and the Alborz}

In our model we observe slow velocities in the shallow upper mantle $(<175 \mathrm{~km})$ beneath central Iran and the Alborz (anomaly CIL). Voluminous high-velocity bodies are observed between 200 to $350 \mathrm{~km}$ depth (anomaly $\mathrm{CIH}$ ), beneath the southern flank of the Alborz Mountains and adjacent regions in central Iran (e.g., Fig. 5e). 
Previous studies have reported slow propagation of body and surface waves and high attenuation rates across the Turkish-Iranian Plateau (e.g., Al-Lazki et al., 2004; Maggi and Priestley, 2005; Al-Damegh et al., 2004; Kaviani et al., 2007; Mahmoodabadi et al., 2019). These observations have led many authors to suggest that central Iran has a thin lithosphere and a warm upper mantle. The LAB depth beneath the southern side of the Alborz Mountains calculated by

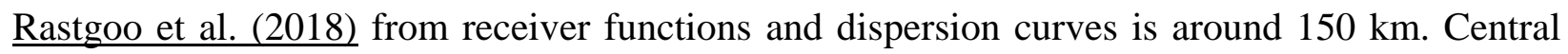
Iran is an elevated plateau with a surface relief of $1000-1500 \mathrm{~m}$ v. ilt during the course of the collision. Despite its relatively high topography, it is only mod-raiziy thickened compared to the Zagros. The measured Moho depths from receiver functı 's in central Iran range from $42 \mathrm{~km}$ north of the Zagros suture (Paul et al., 2006) to $48 \mathrm{k}$ - just south of the Alborz Mountains (Radjaee et al., 2010). Hatzfeld and Molnar $\left(\underline{\imath}^{1} J\right)$ through a detailed analysis of available geologic, present-day kinematics of dc or lation, and deep structure data, discussed the possibility of convective removal of the nantle lid in Tibet and in central Iran. They argued that the low seismic velocities in the $\cdots$ m r most mantle just below the Moho depth beneath both plateaus are consistent with $\mathrm{L}_{\mathrm{a}}{ }^{\mathrm{a}}$-Cenozoic removal of the mantle lithosphere. Several recent seismic tomographies in $T_{1}$ bet have produced strong evidence for lithospheric foundering/delamination 's a result of continental collision (Ren and Shen, 2008; Chen et al., 2017; Huang et al., 2019). The seismic structure of these models consists of a shallow lowvelocity zone in the uppermost mantle sitting over a deeper high-velocity body that extends as deep as the mantle transition zone. In the central Iranian Plateau, the seismic structure of the upper mantle is much less clear than in Tibet and Hatzfeld and Molnar (2010) were not able to present unequivocal evidence from seismic tomography for convective removal of the mantle lithosphere. Seismological studies remain so far inconclusive on the hypothesis of mantle 
delamination in central Iran. The low-resolution surface wave study by Maggi and Priestley $\underline{(2005)}$ in western Asia mapped a low-velocity upper mantle beneath central Iran which was interpreted as an indicator of a thin delaminated lithosphere and a warm shallow mantle. The regional P wave tomography by Mahmoodabadi et al. (2019) has revealed a similar low-velocity shallow structure, but the authors invoked the subduction model by Verdel et al. (2011) to explain their observations. According to Verdel et al. (2011), flat subduction beneath the Eurasian margin in the Cretaceous was followed by slab roll-back, เ xtension, and magmatism in central Iran and asthenospheric upwelling during the Eocene, "es...ing in a pre-collisional thin lithosphere and warm upper mantle on the Eurasian s.te. Petrological evidence for postcollisional delamination in northern Iran comes from i region of Damavand, a Quaternary volcano in central Alborz. Davidson et al. $\left(2 \underline{n^{1}}{ }^{1}\right.$; nd Liotard et al. (2008) argued that the geochemistry of the Damavand magmati. $m$, oints to lithospheric delamination in the Alborz. Shabanian et al. (2012) analyzed structur.1 controls on the Alborz volcanism in a post-collisional setting and proposed that the vol ^ani-activity of Damavand has been the result of magma generation due to a rising asthe. sspuere following lithospheric delamination in a transtensional environment. Rastgoo et $a^{1}-\underline{(218)}$ used their 2-D seismic profile along the southern flank of the Alborz Mountains to ver ${ }^{c} \mathrm{v}$ the structural model proposed by Shabanian et al. (2012). In western and central Alborz their model revealed a low-velocity layer in the 50-100 km depth range and a higher-velocity zone at $100-150 \mathrm{~km}$ depth. The spatial distribution of these velocity zones was interpreted as the result of post-collisional delamination of the lower part of the western Alborz lithosphere.

The previous seismological studies proposing delamination in central Iran, have only provided evidence for a thin "delaminated" lithosphere, without revealing anything that can be taken as 
proof for the presence of the sunken root itself. In several of our profiles and depth plots, the high-velocity anomaly $\mathrm{CIH}$ can be spotted at different depths between 200 and $350 \mathrm{~km}$. It is the best observed in the northern margin of central Iran and the southern side of the Alborz range. The $\mathrm{CIH}$ anomaly progressively deepens from northwest to southeast (compare successive profiles in Fig. 6 and 7), suggesting a foundering body at different stages of descent. We suggest that the $\mathrm{CIH}$ body might offer tangible evidence for the sunken root. In terms of depth interval and vertical configuration, the $\mathrm{CIH}$ anomaly is similar to what seis.ric studies mentioned above have described in Tibet. François et al. (2014) through r.mu. subduction, attempted to test the mechanisms for the bu ${ }^{1}$ dup of dynamic topography in the central Iranian Plateau. They showed that a recent slab $\cdot$ eak-off (5-10 Ma) after the onset of collision, could have indirectly initiated a man ${ }^{*}$. low field beneath the overriding plate, resulting in the delamination of the ur er plate lithospheric mantle. A late-stage isostatic readjustment of the uplifted plateau rould follow without undergoing significant crustal thickening. Their successful mode $v$ e able to produce small-scale convective instabilities beneath the upper plate with wa relengths comparable to the size of the fast anomalies we have observed in our tomographin $1 \mathrm{n} \sim \mathrm{del}$.

\section{Conclusions}

Figure 9 summarizes our findings of the lithospheric and upper mantle structure beneath the Zagros collision zone. Our tomographic study documents variations of lithospheric thickness between the Zagros and central Iran and a post-collisional slab detachment around $250 \mathrm{~km}$ depth. If we assume that the detachment occurred right beneath the base of the subducted Arabian continental margin, then the maximum thickness of the continental root must be no greater than $225-250 \mathrm{~km}$. This would imply a doubling of the Zagros lithosphere as a result of collision. The 
absence of high-velocity anomalies far north of the MZT at the lithospheric depth range indicates that the lithosphere's thickening has not propagated into the interior of central Iran.

The high-velocity anomalies at 200-300 km depth beneath central Iran suggest the presence of fragments of delaminated mantle lithosphere. They also suggest a post-collisional slab break-off in central Zagros which seems to be at an earlier stage in NW Zagros compared to central Zagros. From the shallow depth of the top of the detached slab we infer that the break-off is recent (5-10 Ma), in good agreement with other geological recor is.

Effective detachment of an oceanic slab from continenta' litıusphere is often followed by the upwelling of the asthenosphere through slab gaps, ad action, slab retreat, and eventually volcanism and exhumation of ultra-high-pressur $1 \mathrm{o}$ ks, which are not currently observed in

central Iran. On the other hand, the lack of der $\rho$ sessmicity, especially deep extensional events in the Zagros, indicates that the subductec slab does not exert gravitational pull on the base of the continental plate. To reconcile these ar pa rently contradictory observations, we propose that slab break-off in NW Zagros is very : ouıg.

\section{Acknowledgments}

This research was funded by several IASBS internal grants. M.V. benefited from support provided by the Ministry of Science, Research and Technology of Iran and Laboratoire Géosciences Environnement Toulouse - GET. We acknowledge ISC and INSN for use of their permanent station data. The Zagros01 and Zagros03 arrays were installed by LGIT, Grenoble and IIEES, Tehran. The CIGSIP array was supported by the Strategic Priority Research Program (B) (Grant no. XDB03010802) and the International Partnership Program (GIH21776) of the Chinese Academy of Sciences. The IASBS-CAM arrays were jointly operated by IASBS and 
Univ. of Cambridge. Maps were prepared using the Generic Mapping Tools (Wessel \& Smith 1998). We thank associate editor Ling Chen, Zhouchuan Huang, and two other anonymous reviewers for their valuable comments and critique of the manuscript.

\section{References}

Agard, P., Omrani, J., Jolivet, L., Whitechurch, H., Vriely ־ュk, B., Spakman, W., Monié, P., Meyer, B. and Wortel, R., 2011. Zagros orogen." a subduction-dominated process. Geological Magazine, 148(5-6), pp. 692-725. '.tps //doı.org/10.1017/S001675681100046X.

Aki, K., Christoffersson, A. and Hus hye, E.S., 1977. Determination of the three-dimensional seismic structure of the lithosp'lete. Journal of Geophysical Research, 82(2), pp. 277-296. https://doi.org/10.1029/I $\underline{302}$ i002p00277.

Al-Damegh, K., Sandvol, ․, ,l-Lazki, A. and Barazangi, M., 2004. Regional seismic wave propagation $\left(\sigma^{\sigma}\right.$ and $\mathrm{jn}$ ) and Pn attenuation in the Arabian Plate and surrounding regions. Geophysical Juurnal International, 157(2), pp. 775-795. https://doi.org/10.1111/j.1365246X.2004.02246.X.

Alinaghi, A., Koulakov, I. and Thybo, H., 2007. Seismic tomographic imaging of P-and S-waves velocity perturbations in the upper mantle beneath Iran. Geophysical Journal International, 169(3), pp. 1089-1102. https://doi.org/10.1111/j.1365-246X.2007.03317.x.

Al-Lazki, A.I., Sandvol, E., Seber, D., Barazangi, M., Turkelli, N. and Mohamad, R., 2004. Pn tomographic imaging of mantle lid velocity and anisotropy at the junction of the Arabian, 
Eurasian and African plates. Geophysical Journal International, 158(3), pp. 1024-1040. https://doi.org/10.1111/j.1365-246X.2004.02355.x.

Arvin, S., Sobouti, F., Priestley, K., Ghods, A., Motaghi, K., Tilmann, F. and Eken, T., 2021. Seismic anisotropy and mantle deformation in NW Iran inferred from splitting measurements of SK (K) S and direct S phases. Geophysical Journal International, 226(2), pp.1417-1431. https://doi.org/10.1093/gji/ggab181.

Asudeh, I., 1982. Pn velocities beneath Iran. Earth and Planetary cience Letters, 61(1), pp. 136142. https://doi.org/10.1016/0012-821X(82)90046-2.

Ballato, P., Mulch, A., Landgraf, A., Strecker, M.R., Dalcc ai, M I., Friedrich, A. and Tabatabaei, S.H., 2010. Middle to late Miocene Middle Eas` ${ }^{\prime}$ rn । limate from stable oxygen and carbon isotope data, southern Alborz Mountains iv Iran. Earth and Planetary Science Letters, 300(1-2), pp. 125-138. https://doi.or ? 9.. 16/j.epsl.2010.09.043.

Bijwaard, H., Spakman, W. and Engdahl, E.h 1998. Closing the gap between regional and global travel time tomography. Jov n. ' of Geophysical Research: Solid Earth, 103(B12), pp. 30055-30078. https://doi.气.g/L.1029/98JB02467.

Chang, S.J., Van Der Lee, S., Fınnagan, M.P., Bedle, H., Marone, F., Matzel, E.M., Pasyanos, M.E., Rodgers, t.J., Romanowicz, B. and Schmid, C., 2010. Joint inversion for threedimensional S ves scity mantle structure along the Tethyan margin. Journal of Geophysical Research: Solid Earth, 115(B8). https://doi.org/10.1029/2009JB007204.

Chen, M., Niu, F., Tromp, J., Lenardic, A., Lee, C., Cao, W. and Ribeiro, J., (2017). Lithospheric foundering and underthrusting imaged beneath Tibet. Nature Communication, 8, 15659 (2017). https://doi.org/10.1038/ncomms15659. 
Chevrot, S., 2002. Optimal measurement of relative and absolute delay times by simulated annealing. Geophysical Journal International, 151(1), pp. 164-171. https://doi.org/10.1046/j.1365-246X.2002.01755.x.

Chiu, H.Y., Chung, S.L., Zarrinkoub, M.H., Mohammadi, S.S., Khatib, M.M. and Iizuka, Y., 2013. Zircon $\mathrm{U}-\mathrm{Pb}$ age constraints from Iran on the magmatic evolution related to Neo-Tethyan subduction and Zagros orogeny. Lithos, 162, pp. 70-87. https://doi.org/10.1016/j.lithos.2013.01.006.

Davidson, J. P., Hassanzadeh, J., Berzins, R., Stockli, D.F., Bas ıukooh, B., Turrin, B., and Pandamouz, A., 2004. The geology of Damavand vilerno, Alborz Mountains, northern Iran. Geological Society of America Bulletin, 11 , 16 -29. https://doi.org/10.1130/B25344.

Dercourt, J. Ricou, L. E., and Vrielynck, B., צ3. Atlas Tethys, paleoenvironmental maps. Elsevier, New York.

Duretz, T., Schmalholz, S.M. and Gerya, T.レ. 2012. Dynamics of slab detachment. Geochemistry, Geophysics, Geosystems, 13(?). ttps://doi.org/10.1029/2011GC004024.

Duretz, T., Gerya, T.V. and May D.r.., 2011. Numerical modelling of spontaneous slab breakoff and subsequent top (araphic response. Tectonophysics, 502(1-2), pp. 244-256. https://doi.org/10 101 5/j.tecto.2010.05.024.

Egan, S.S., Mosar, J., B unet, M.F. and Kangarli, T., 2009. Subsidence and uplift mechanisms within the South Caspian Basin: insights from the onshore and offshore Azerbaijan region. Geological Society, London, Special Publications, 312(1), pp. 219-240. https://doi.org/10.1144/SP312.11.

Evans, J., Achauer, U., Iyer, H. and Hirahara, K., 1993. Teleseismic velocity tomography using the ACH method: theory and application to continental scale. In: Iver, H.M., and Hirahara, K., (Eds.), Seismic Tomography: Theory and Practice, Chapman \& Hall., London, pp. 319-360. 
François, T., Burov, E., Agard, P. and Meyer, B., 2014. Buildup of a dynamically supported orogenic plateau: Numerical modeling of the Zagros/Central Iran case study. Geochemistry, Geophysics, Geosystems, 15(6), pp. 2632-2654. https://doi.org/10.1002/2013GC005223.

Goes, S., Govers, R. and Vacher, A.P., 2000. Shallow mantle temperatures under Europe from P and S wave tomography. Journal of Geophysical Research: Solid Earth, 105(B5), pp. 11153-11169. https://doi.org/10.1029/1999JB900300.

Guest, B., Horton, B.K., Axen, G.J., Hassanzadeh, J. and McIntc ‘', W.C., 2007. Middle to late Cenozoic basin evolution in the western Alborz Mount: ins: Implications for the onset of collisional deformation in $\quad 10^{\text {the }} \cdot \mathrm{n} \quad$ Iran. Tectonics, 26(6). https://doi.org/10.1029/2006TC002091.

Guest, B., Axen, G.J., Lam, P.S. and Hassanzadeh J., 2006. Late Cenozoic shortening in the westcentral Alborz Mountains, norther.. 'ra' by combined conjugate strike-slip and thinskinned deformation. Geosphere, 2(1), . p. 35-52. https://doi.org/10.1130/GES00019.1.

Hafkenscheid, E., Wortel, M.J.R. a a Spakman, W., 2006. Subduction history of the Tethyan region derived from sc sml tomography and tectonic reconstructions. Journal of Geophysical Research. Soid Earth, 111(B8). https://doi.org/10.1029/2005JB003791.

Hatzfeld, D. and Moln c, I , 2010. Comparisons of the kinematics and deep structures of the Zagros and Himal lya and of the Iranian and Tibetan plateaus and geodynamic implications. Reviews of Geophysics, 48(2). https://doi.org/10.1029/2009RG000304.

Huang, Z., Wang, L., Xu, M., Zhao, D., Mi, N., and Yu, D., 2019. P and S wave tomography beneath the SE Tibetan Plateau: Evidence for lithospheric delamination. Journal of Geophysical Research: Solid Earth. https://doi.org/10.1029/2019JB017430.

Kaviani, A., Mahmoodabadi, M., Rümpker, G., Pilia, S., Tatar, M., Nilfouroushan, F., YaminiFard, F., Moradi, A. and Ali, M.Y., 2021. Mantle-flow diversion beneath the Iranian plateau induced by Zagros' lithospheric keel. Scientific reports, 11(1), pp.1-12. 
Kaviani, A., Paul, A., Moradi, A., Mai, P.M., Pilia, S., Boschi, L., Rümpker, G., Lu, Y., Tang, Z. and Sandvol, E., 2020. Crustal and uppermost mantle shear wave velocity structure beneath the Middle East from surface wave tomography. Geophysical Journal International, 221(2), pp. 1349-1365. https://doi.org/10.1093/gji/ggaa075.

Kaviani, A., Sandvol, E., Moradi, A., Rümpker, G., Tang, Z., and Mai, P. M., 2018. Mantle transition zone thickness beneath the Middle East: Evidence for segmented Tethyan slabs, delaminated lithosphere, and lower mantle upwelling. Jou ‘al of Geophysical Research: Solid Earth, 123, 4886-4905. https://doi.org/10.1029/201، IBO $\underline{15627 .}$

Kaviani, A., Paul, A., Bourova, E., Hatzfeld, D., Pedersen t. ad Mokhtari, M., 2007. A strong seismic velocity contrast in the shallow mant ${ }^{1}:$ ac oss the Zagros collision zone (Iran). Geophysical Journal International, 171(1', pp. 399-410. https://doi.org/10.1111/j.1365246X.2007.03535.x.

Karasözen, E., Nissen, E., Bergman, E.A. a. ł Ghods, A., 2019. Seismotectonics of the Zagros (Iran) from orogen-wide, rals raıd earthquake relocations. Journal of Geophysical Research: Solid Earth, 121/8), ,p.9109-9129. https://doi.org/10.1029/2019JB017336.

Koulakov, I., 2011. High-frequ `ncy P and S velocity anomalies in the upper mantle beneath Asia from inversion if $\mathrm{u}$ orldwide traveltime data. Journal of Geophysical Research: Solid Earth, 116(B4) h sps://doi.org/10.1029/2010JB007938.

Liotard, J. M., J. M. Dautria, D. Bosch, M. Condomines, M. Mehdizadeh, and J.-F. Ritz, 2008. Origin of the absarokite-banakite association of the Damavand volcano (Iran): Trace elements and $\mathrm{Sr}, \mathrm{Nd}, \mathrm{Pb}$ isotope constraints, Int. J. Earth Sci., 97, 89-102. https://doi.org/10.1007/s00531-006-0159-6. 
Maggi, A. and Priestley, K., 2005. Surface waveform tomography of the Turkish-Iranian plateau. Geophysical Journal International, 160(3), pp.1068-1080. https://doi.org/10.1111/j.1365246X.2005.02505.x.

Mahmoodabadi, M., Yaminifard, F., Tatar, M. and Kaviani, A., 2020. Shear wave velocity structure of the upper-mantle beneath the northern Zagros collision zone revealed by nonlinear teleseismic tomography and Bayesian Monte-Carlo joint inversion of surface wave dispersion and teleseismic P-wave coda. Physics of the Farth and Planetary Interiors. https://doi.org/10.1016/j.pepi.2020.106444.

Mahmoodabadi, M., Yaminifard, F., Tatar, M., Kaviani, A a.d Motaghi, K., 2019. Upper-mantle velocity structure beneath the Zagros collision z ne, I Jentral Iran and Alborz from nonlinear teleseismic tomography. Geophysical wn nal International, 218(1), pp. 414-428. https://doi.org/10.1093/gji/ggz160.

Maupin, V., 2020. Combining asynchronu 's data sets in regional body-wave tomography. Geophysical Journal international, 224(1), pp. 401-415. https://doi.org/10.1093/gi ggant73.

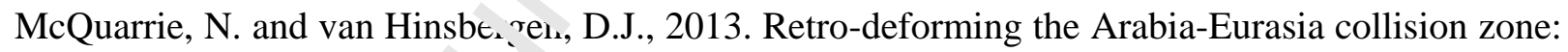
Age of collision vers is magnitude of continental subduction. Geology, 41(3), pp. 315-318. https://doi.org/10. 130/G33591.1.

Mohammadi, N., Sodoudi, F., Mohammadi, E., and Sadidkhouy, A., 2013. New constraints on lithospheric thickness of the Iranian plateau using converted waves. Journal of Seismology, 17:883-895. https://doi.org/10.1007/s10950-013-9359-2.

Motaghi, K., Shabanian, E. and Kalvandi, F., 2017a. Underplating along the northern portion of the Zagros suture zone, Iran. Geophysical Journal International, 210(1), pp.375-389. https://doi.org/10.1093/gji/ggx168. 
Motaghi, K., Shabanian, E., Tatar, M., Cuffaro, M. and Doglioni, C., 2017b. The south Zagros suture zone in teleseismic images. Tectonophysics, 694, pp. 292-301. https://doi.org/10.1016/j.tecto.2016.11.012.

Motaghi, K., Tatar, M., Shomali, Z.H., Kaviani, A. and Priestley, K., 2012. High resolution image of uppermost mantle beneath NE Iran continental collision zone. Physics of the Earth and Planetary Interiors, 208, pp. 38-49. https://doi.org/10.1016/j.pepi.2012.07.006.

Omrani, J., Agard, P., Whitechurch, H., Benoit, M., Prouteau, `. and Jolivet, L., 2008. Arcmagmatism and subduction history beneath the Zagros Mou tains, Iran: a new report of adakites and geodynamic consequences. Lı.'ho, 106(3-4), pp. 380-398. https://doi.org/10.1016/j.lithos.2008.09.008.

Paige, C.C. and Saunders, M.A., 1982. LSQR: An al,orithm for sparse linear equations and sparse least squares. ACM Transactions „. M. Mthematical Software (TOMS), 8(1), pp. 43-71. https://doi.org/10.1145/355984.35598;

Paul, A., Hatzfeld, D., Kaviani, A., 1с.`r. M. and Péquegnat, C., 2010. Seismic imaging of the lithospheric structure of he Zagros mountain belt (Iran). Geological Society, London, Special Publications, J?ク(i), pp. 5-18. https://doi.org/10.1144/SP330.2.

Paul, A., Kaviani, A.. H tzte`d, D., Vergne, J. and Mokhtari, M., 2006. Seismological evidence for crustal-scale thrı sting in the Zagros mountain belt (Iran). Geophysical Journal International, 166(1), pp. 227-237. https://doi.org/10.1111/j.1365-246X.2006.02920.x.

Pirouz, M., Avouac, J.P., Hassanzadeh, J., Kirschvink, J.L. and Bahroudi, A., 2017. Early Neogene foreland of the Zagros, implications for the initial closure of the Neo-Tethys and kinematics of crustal shortening. Earth and Planetary Science Letters, 477, pp. 168-182. https://doi.org/10.1016/j.eps1.2017.07.046. 
Priestley, K., McKenzie, D., Barron, J., Tatar, M. and Debayle, E., 2012. The Zagros core: deformation of the continental lithospheric mantle. Geochemistry, Geophysics, Geosystems, 13(11). https://doi.org/10.1029/2012GC004435.

Radjaee, A., Rham, D., Mokhtari, M., Tatar, M., Priestley, K. and Hatzfeld, D., 2010. Variation of Moho depth in the central part of the Alborz Mountains, northern Iran. Geophysical Journal International, 181(1), pp. 173-184. https://doi.org/10.1111/j.1365-246X.2010.04518.x.

Rahmani, M., Motaghi, K., Ghods, A., Sobouti, F., Talebian, M., \& Y. and Chen, L., 2019. Deep velocity image of the north Zagros collision zone (Ira ^) fo om regional and teleseismic tomography. Geophysical Journal Internaion rl 219(3), pp. 1729-1740. https://doi.org/10.1093/gji/ggz393.

Rastgoo, M., Rahimi, H., Motaghi, K., Shabanian E, Romanelli, F. and Panza, G.F., 2018. Deep structure of the Alborz Mountains $r_{j}{ }_{j}{ }^{\prime} 11_{\star}{ }^{+}$inversion of $\mathrm{P}$ receiver functions and dispersion curves. Physics of the Earth and Planetary Interiors, 277, pp. 70-80. https://doi.org/10.1016/j.pepi. $\underline{\underline{v}}=9 . \underline{1.011}$.

Ren, Y. and Shen, Y., 2008. Fin e fruquency tomography in southeastern Tibet: evidence for the causal relationship bet, re $\epsilon_{. i}$ mantle lithosphere delamination and the north-south trending rifts. Journa of Geophysical Research: Solid Earth, 113(B10). https://doi.org/1 $\underline{0}$. 029/2008JB005615.

Sadeghi-Bagherabadi, A., Margheriti, L., Aoudia, A. and Sobouti, F., 2018. Seismic anisotropy and its geodynamic implications in Iran, the easternmost part of the Tethyan Belt. Tectonics, 37(12), pp.4377-4395.https://doi.org/10.1029/2018TC005209.

Şengör, A.M.C., and Natal'in, B.A., 1996. Paleotectonics of Asia: fragments of a synthesis. The tectonic evolution of Asia, pp. 486-640. 
Shabanian, E., Acocella, V., Gioncada, A., Ghasemi, H. and Bellier, O., 2012. Structural control on volcanism in intraplate post collisional settings: Late Cenozoic to Quaternary examples of Iran and Eastern Turkey. Tectonics, 31(3). https://doi.org/10.1029/2011TC003042.

Shad Manaman, N., Shomali, H. and Koyi, H., 2011. New constraints on upper-mantle S-velocity structure and crustal thickness of the Iranian plateau using partitioned waveform inversion. Geophysical Journal International, 184(1), pp. 247-267. https://doi.org/10.1111/j.1365246X.2010.04822.x.

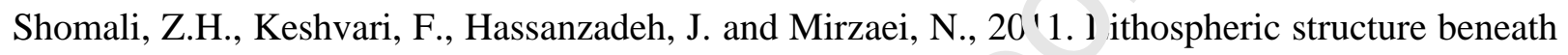
the Zagros collision zone resolved by non-linear tt'as ismic tomography. Geophysical Journal International, 187(1), pp. :94- $06 . \quad$ https://doi.org/10.1111/j.1365246X.2011.05150.x.

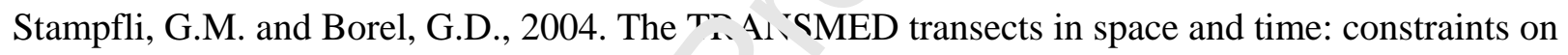
the paleotectonic evolution of the $\boldsymbol{N}_{\text {. }}$ diterranean domain. In: Cavazza, W., Roure, F., Spakman, W., Stampfli, G.ı. Ziegler, P.A. (Eds.), The TRANSMED Atlas. The Mediterranean region fr $m$ c ust to mantle. Springer., Berlin, Heidelberg, pp. 53-80. https://doi.org/10.100/970.3-642-18919-7_3.

Stampfli, G.M. and Bor $\lrcorner$ l, I.D., 2002. A plate tectonic model for the Paleozoic and Mesozoic constrained by dy amic plate boundaries and restored synthetic oceanic isochrons. Earth and Planetary Science Letters, 196 (1-2), pp. 17-33. https://doi.org/10.1016/S0012$\underline{821 X(01) 00588-X}$.

Stöcklin, J., 1968. Structural history and tectonics of Iran: a review. AAPG bulletin, 52(7), pp. 1229-1258. https://doi.org/10.1306/5D25C4A5-16C1-11D7-8645000102C1865D.

Van der Meer, D.G., Van Hinsbergen, D.J. and Spakman, W., 2018. Atlas of the underworld: Slab remnants in the mantle, their sinking history, and a new outlook on lower mantle viscosity. Tectonophysics, 723, pp. 309-448. https://doi.org/10.1016/j.tecto.2017.10.004. 
van Hunen, J. and Allen, M.B., 2011. Continental collision and slab break-off: A comparison of 3D numerical models with observations. Earth and Planetary Science Letters, 302(1-2), pp. 27-37. https://doi.org/10.1016/j.eps1.2010.11.035.

Verdel, C., Wernicke, B.P., Hassanzadeh, J. and Guest, B., 2011. A Paleogene extensional arc flare up in Iran. Tectonics, 30(3). https://doi.org/10.1029/2010TC002809.

Wessel, P. and Smith, W.H., 1998. New, improved version of Generic Mapping Tools released.Eos, Transactions American Geophysical 'nion,79(47), pp. 579-579. https://doi.org/10.1029/98EO00426.

Table1: Sumı ar of network and data information used in this study

\begin{tabular}{|c|c|c|c|c|}
\hline Network name & $\begin{array}{c}\text { No of } \\
\text { stations }\end{array}$ & Operation period & Sensors type & Operating agency \\
\hline Zagros01 & 64 & Nov 2000 to Apr 2001 & $\begin{array}{c}\text { STRECKEISEN } \\
\text { STS2, } \\
\text { CHINESE CDJ, } \\
\text { LENNARTZ } \\
\text { LE3D }\end{array}$ & $\begin{array}{c}\text { LGIT, Grenoble } \\
\text { IIEES, Tehran }\end{array}$ \\
\hline Zagros03 & 35 & May -Nov 200 3 & $\begin{array}{c}\text { GURALP } \\
\text { CMG40, } \\
\text { LENNARTZ } \\
\text { LE3D }\end{array}$ & $\begin{array}{c}\text { LGIT, Grenoble } \\
\text { IIEES, Tehran }\end{array}$ \\
\hline
\end{tabular}




\begin{tabular}{|c|c|c|c|c|}
\hline CIGSIP & 63 & Sep 2013- Oct 2014 & $\begin{array}{c}\text { TRILIUM and } \\
\text { GURALP } \\
\text { broadband }\end{array}$ & $\begin{array}{c}\text { IGGCAS, Beijing } \\
\text { GSI,Tehran } \\
\text { IASBS, Zanjan }\end{array}$ \\
\hline IASBS-CAM1 & 23 & Aug 2008- Jul 2012 & $\begin{array}{c}\text { CMG-3ESP, } \\
\text { CMG-3TD Guralp } \\
\text { system }\end{array}$ & $\begin{array}{c}\text { IASBS, Zanjan } \\
\text { Cambridge, UK }\end{array}$ \\
\hline $\begin{array}{c}\text { IASBS-CAM2 } \\
\text { IRSC }\end{array}$ & 17 & Sep 2014 Jun 2016 & $\begin{array}{c}\text { CMG-3ESP, } \\
\text { CMG-3TD Guralp } \\
\text { system }\end{array}$ & $\begin{array}{c}\text { IASBS, Zanjan } \\
\text { Cambridge, UK }\end{array}$ \\
\hline $\begin{array}{c}\text { Stations } \\
\text { INSN } \\
\text { permanent } \\
\text { stations }\end{array}$ & 17 & $\begin{array}{c}2012-2018 \text { with one } \\
\text { year gaps }\end{array}$ & $\begin{array}{c}\text { Mostly broaciv } n d ~ \\
\text { sensr is }\end{array}$ & IRSC, Tehran \\
\hline
\end{tabular}




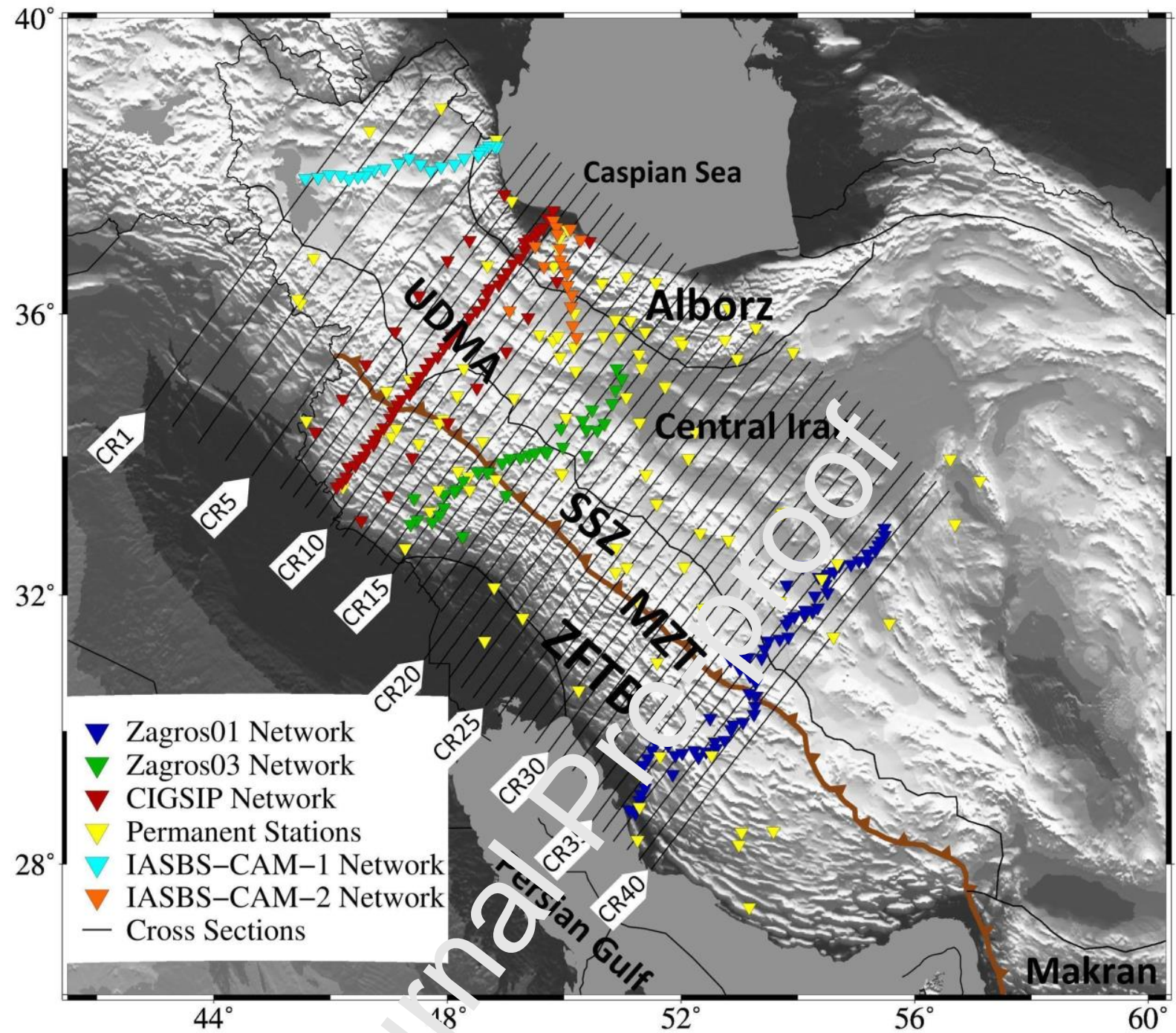

Figure 1. Map showing the seisma net orks used in this study as well as the major tectonic units: Zagros Fold and Thrust Belt (ZFTB), Maiı 7a $7 a_{\odot}$ ros Trust (MZT), Alborz Mountains, Sanandaj-Sirjan Zone (SSZ), Urmia-Dokhtar Magmatic Arc (UDMA), thr ( zntral Iran Microblock, and Makran Subduction Zone. The positions of the crosssections, numbered from 1 to 40, are also shown with black solid lines. 

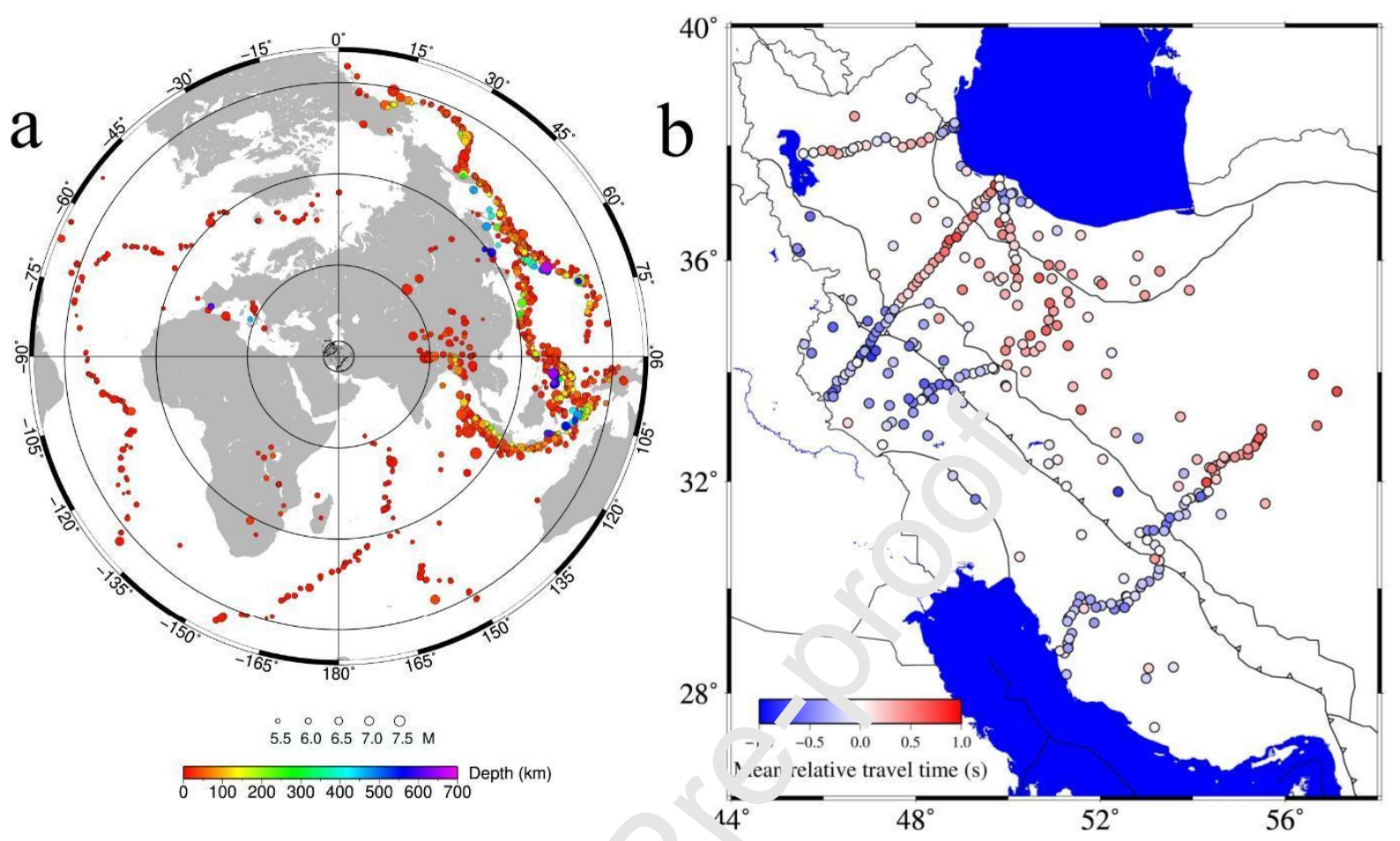

Figure 2. (a) Map showing the epicenters of . Ieseismic events used in this study. Epicentral distances are computed from the center of our tomosnap ir grid. (b) Map showing average station travel time residuals. 
Layer $4,75-100 \mathrm{~km}$

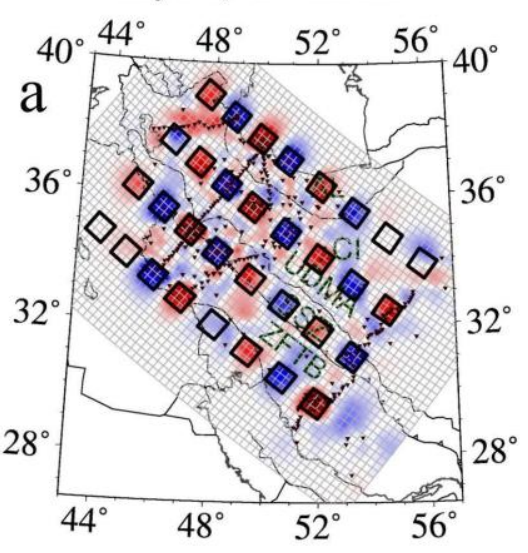

Layer 10, 225 - $250 \mathrm{~km}$

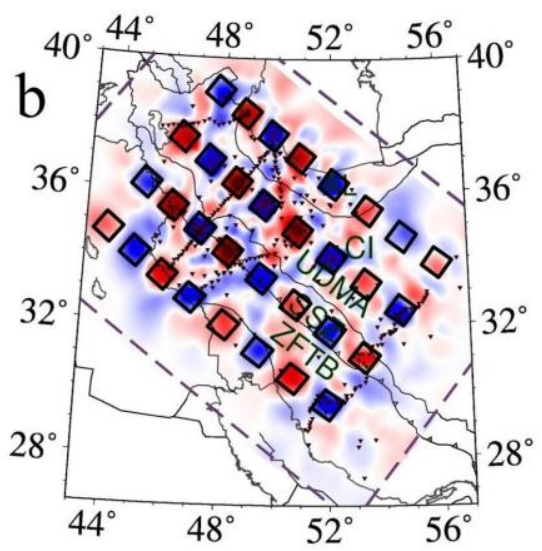

Layer 16, $375-400 \mathrm{~km}$

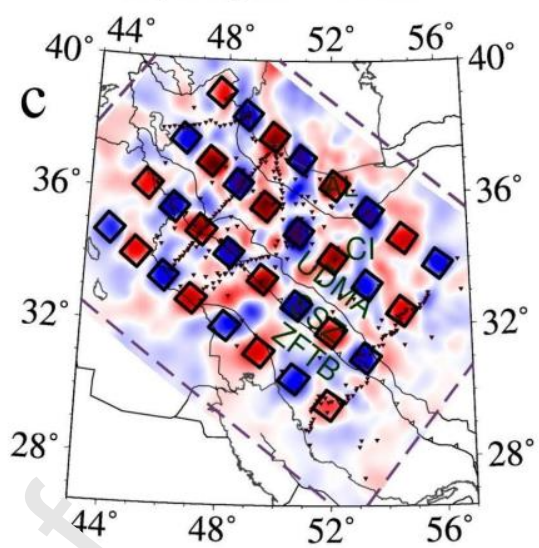

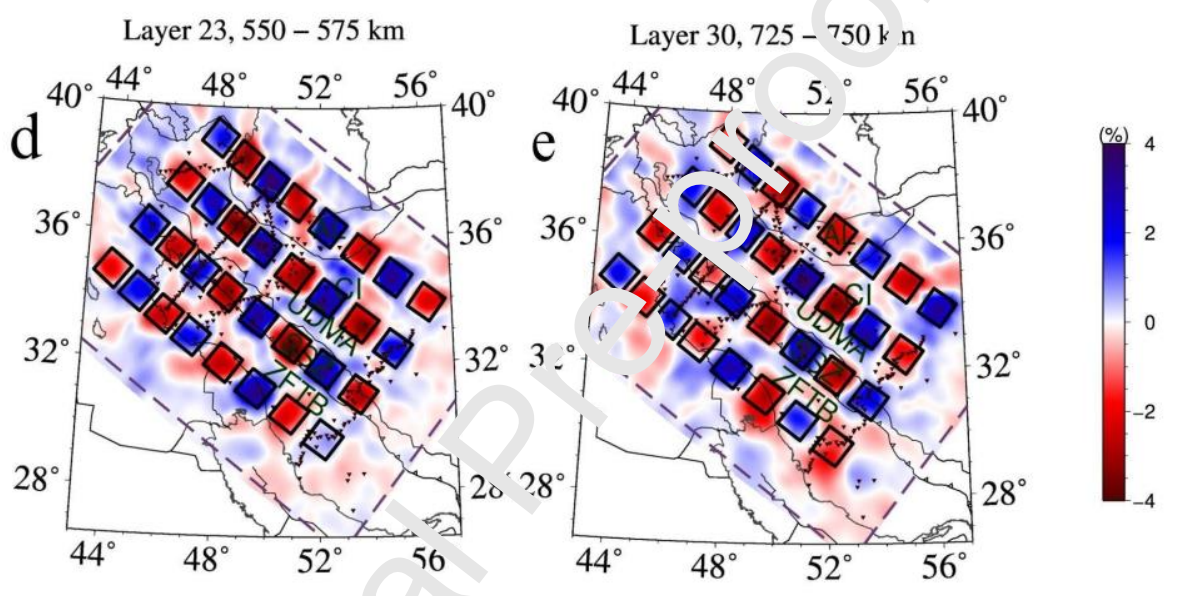

Figure 3. The results of the s, nthe ic five-layer spike inversion test at different depths. The horizontal grid shows the mon's discretization. Solid squares represent the synthetic model, with alternating positive ana $\cdot$ ogutive anomalies. 


\section{Journal Pre-proof}

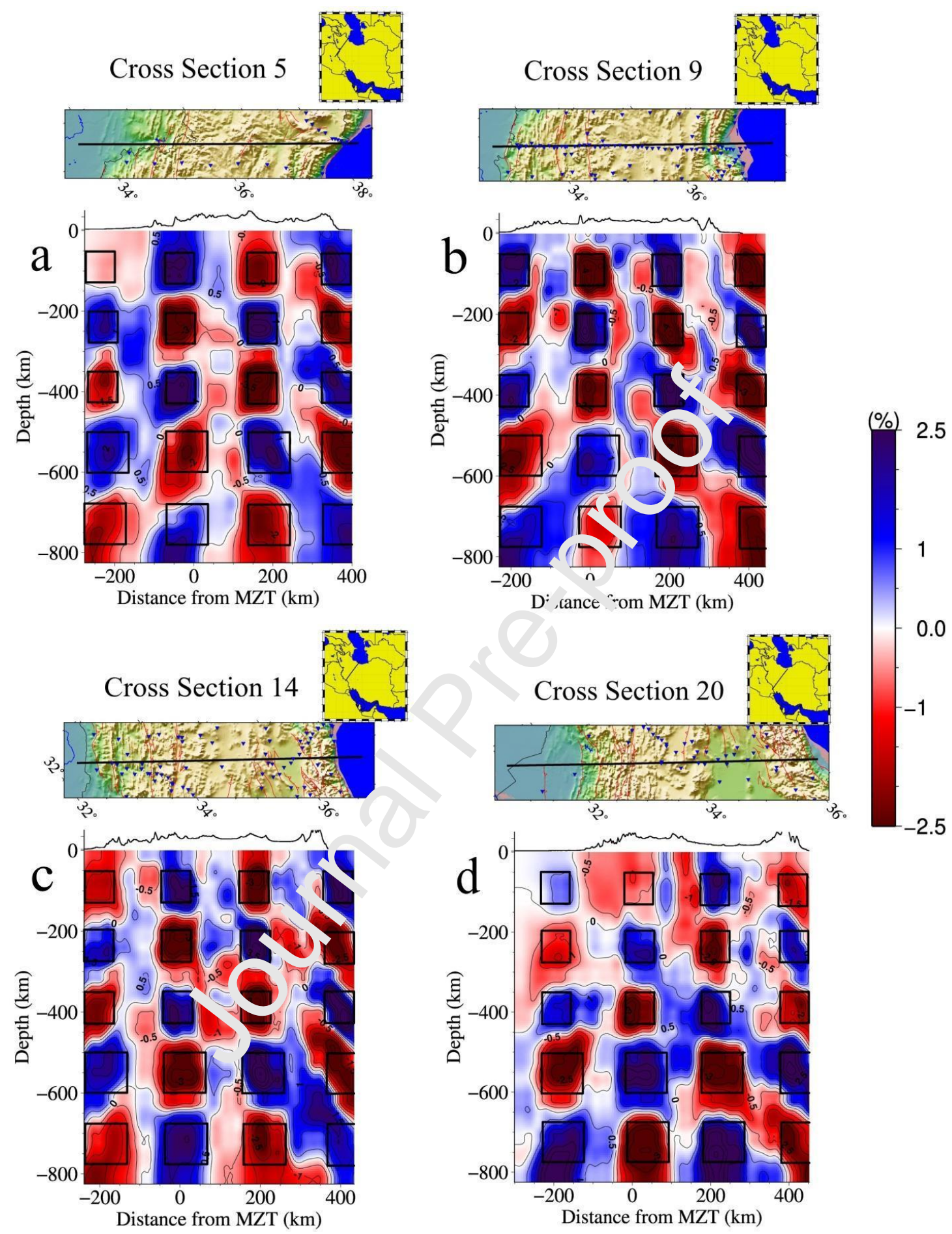

Figure 4. Results of the spike test inversion along 7 cross-sections. Location and surface topography are displayed on the top of each cross-section. Solid squares represent the anomalies in the synthetic model. 

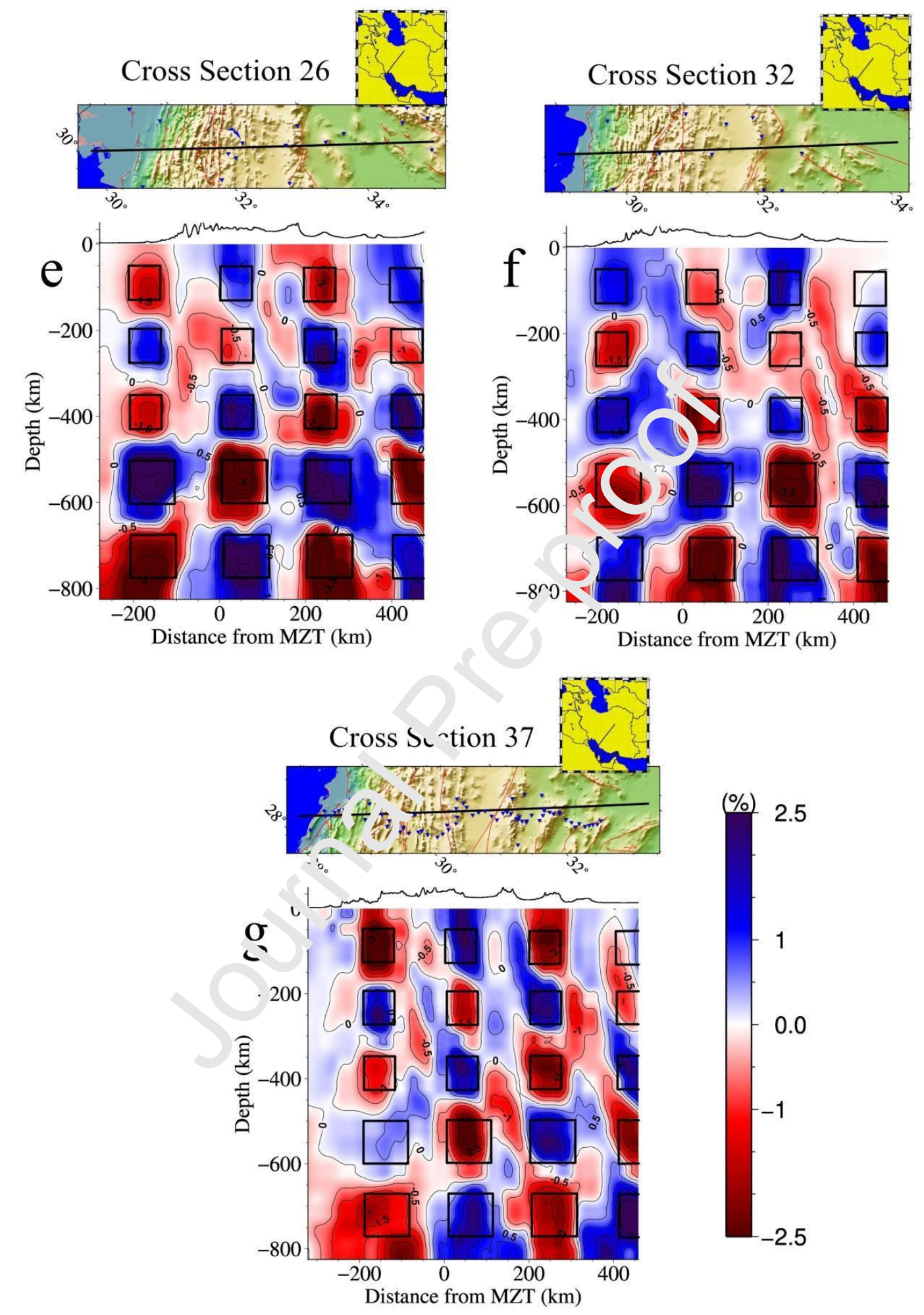

Figure 4. Continued. 
Layer 2, 25 - $50 \mathrm{~km}$

Layer $4,75-100 \mathrm{~km}$
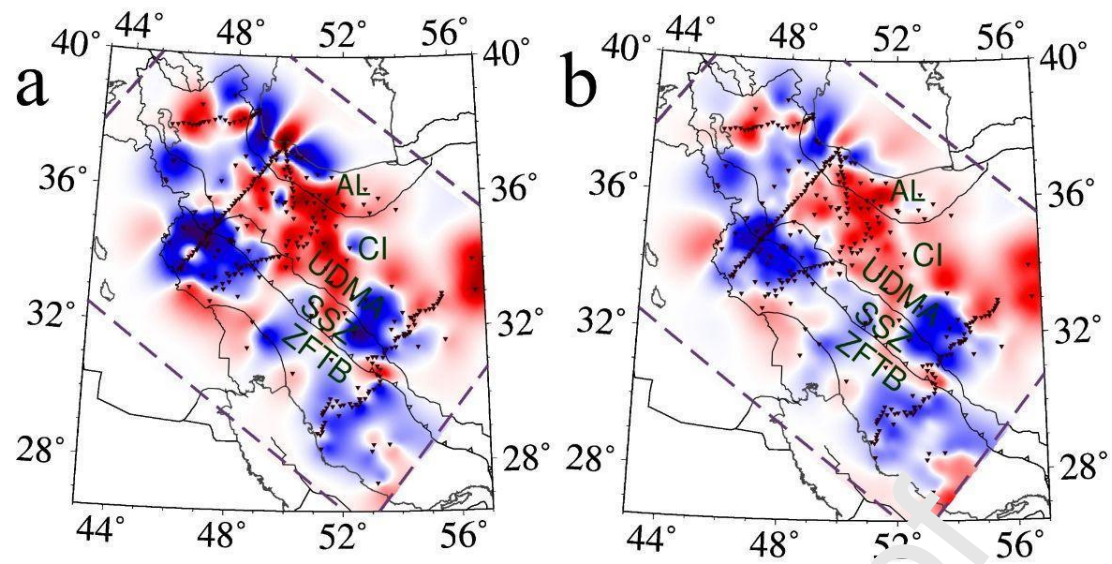

Layer 7, $150-175 \mathrm{~km}$

Layer 9, 20ก- $75 \mathrm{~km}$
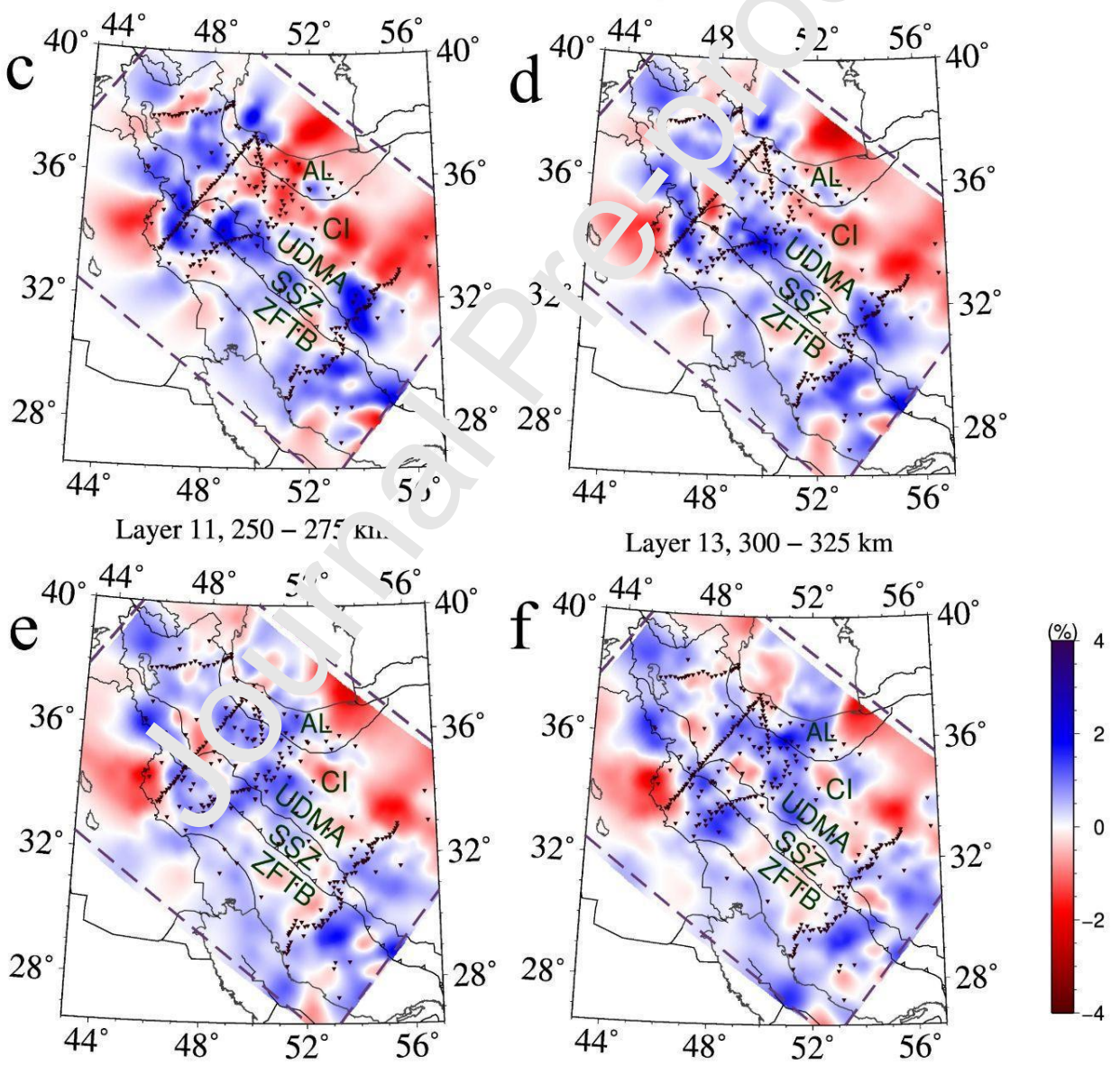

Figure 5. Horizontal sections at 12 different depths in the final model. 
Layer 16, 375 - $400 \mathrm{~km}$

Layer 19, 450 - $475 \mathrm{~km}$
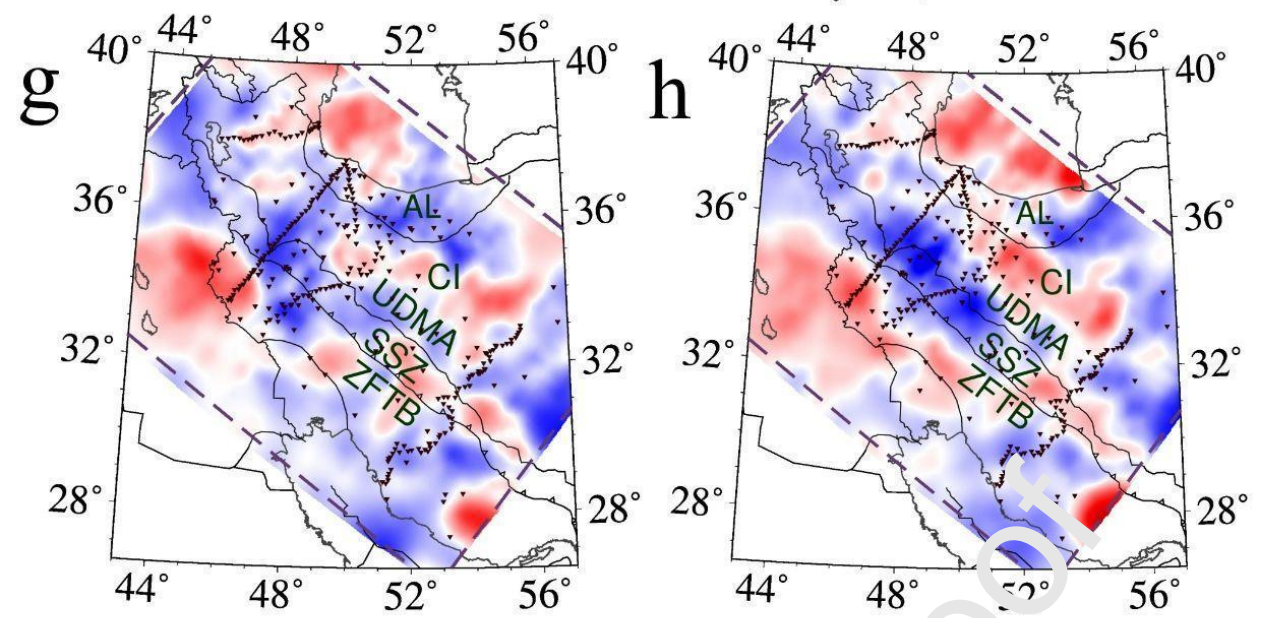

Layer 23, 550 - $575 \mathrm{~km}$

Layer $\left.2^{r}, \iota^{7}\right)-625 \mathrm{~km}$

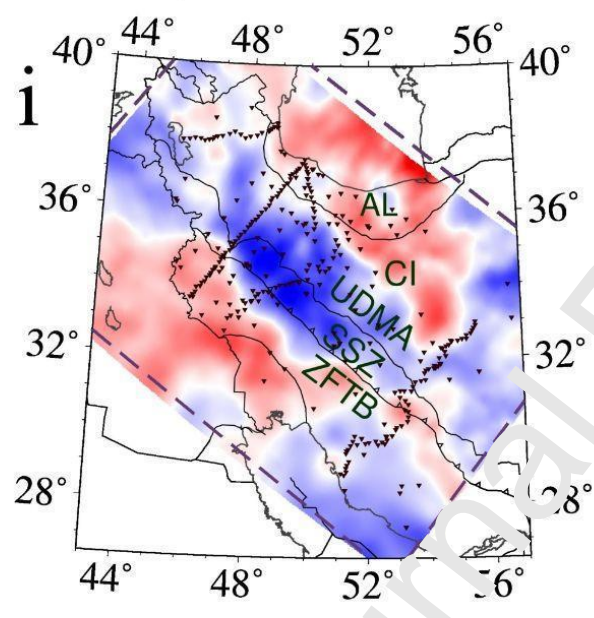

Layer 29, $700-72 . \mathrm{km}$

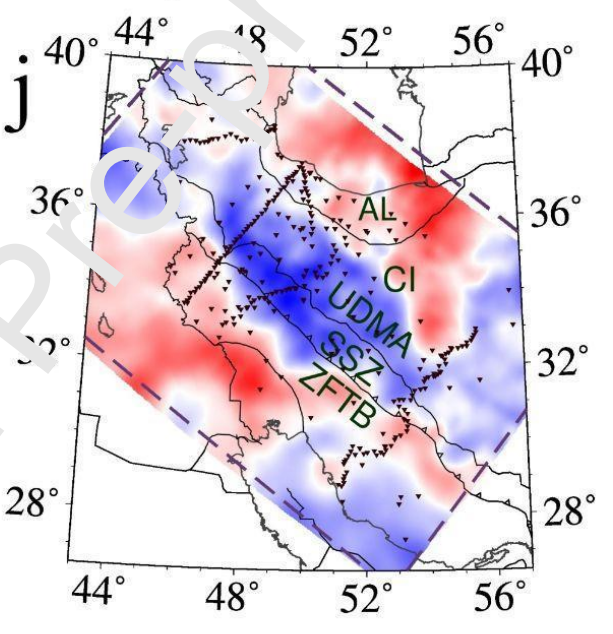

Layer 33, $800-825 \mathrm{~km}$
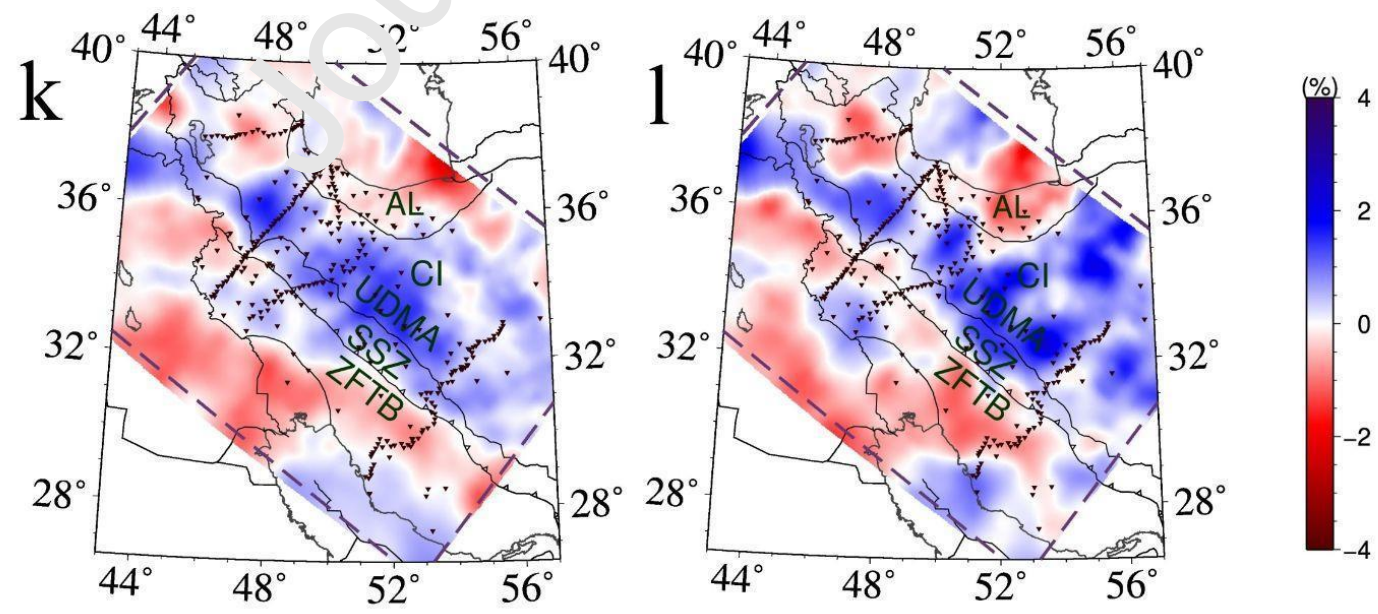

Figure 5. Continued. 


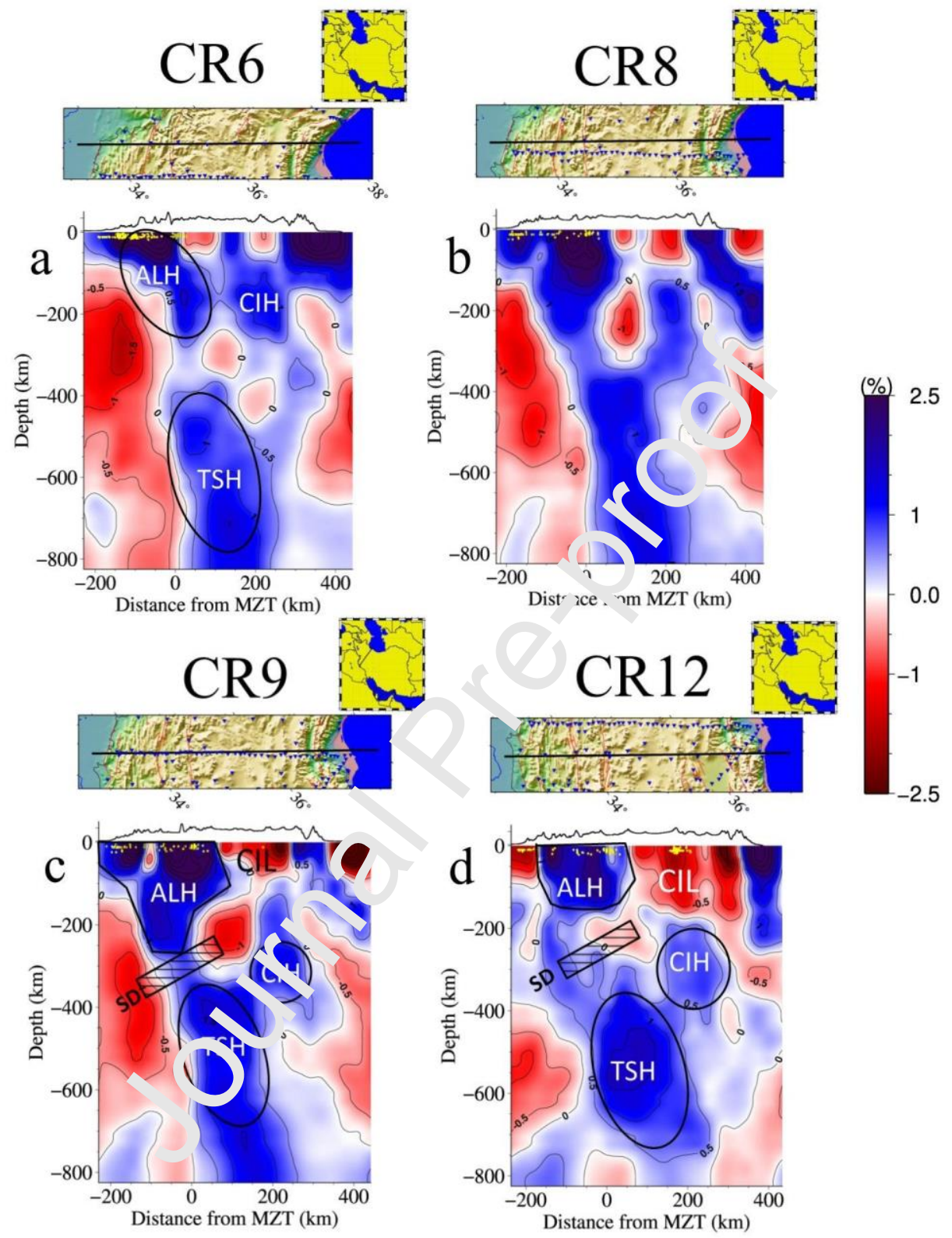

Figure 6. Four vertical cross sections through the western part of the tomographic model. Figure details are the same as in Fig. 4. The major velocity anomalies discussed in the text are outlined: ALH (Arabian lithosphere High), CIL (central Iran Low), CIH (Central Iran High) and TSH (Tethyan Slab High). The hatched rectangle SD denotes the detachment of the subducted slab. Yellow dots represent the hypocenter of earthquakes after Karasözen et al. (2019). 


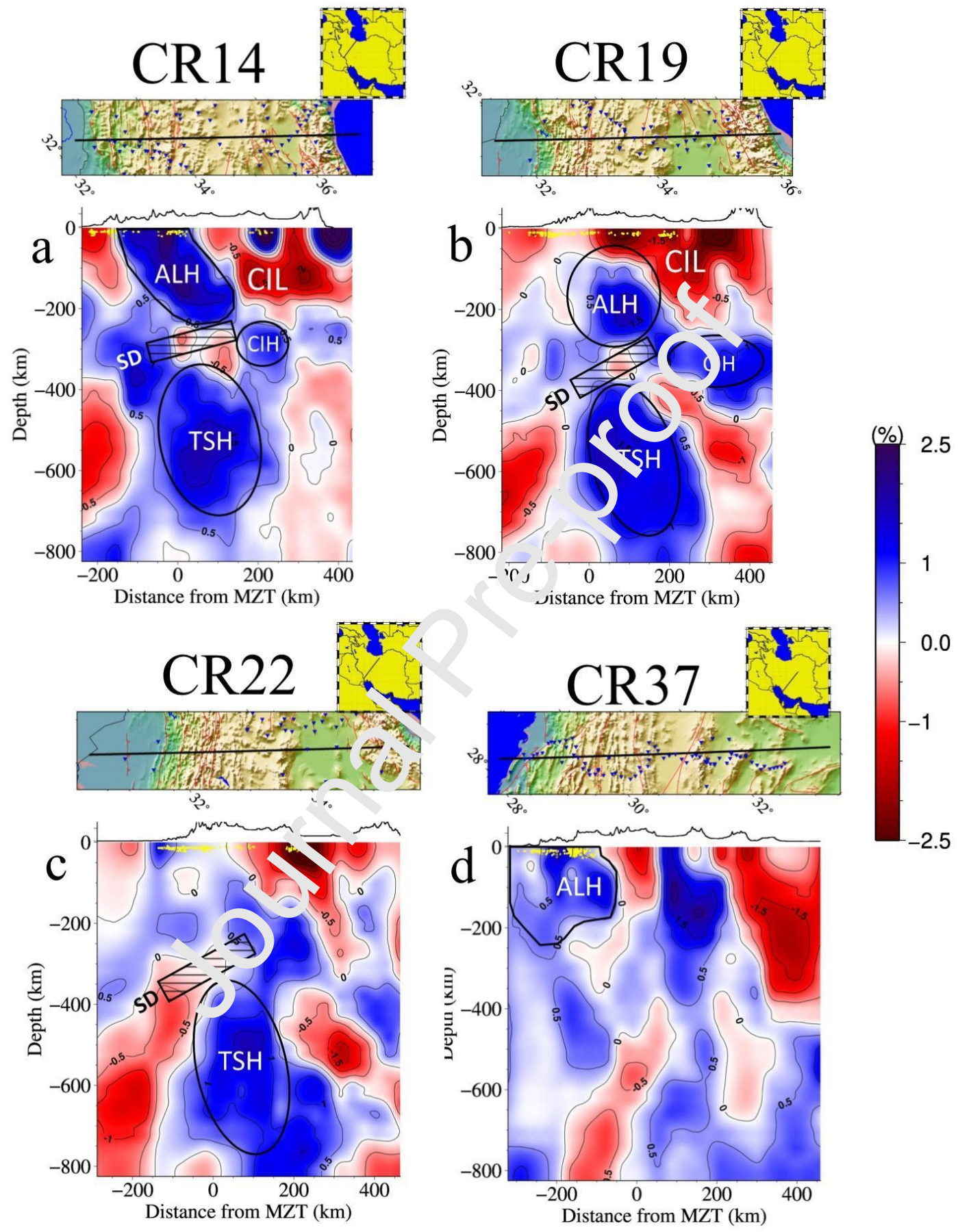

Figure 7. Four vertical cross sections through the eastern part of the tomography model. Figure details are the same as in Fig. 6. SD denotes the slab detachment, which is more clearly seen in central Zagros. 


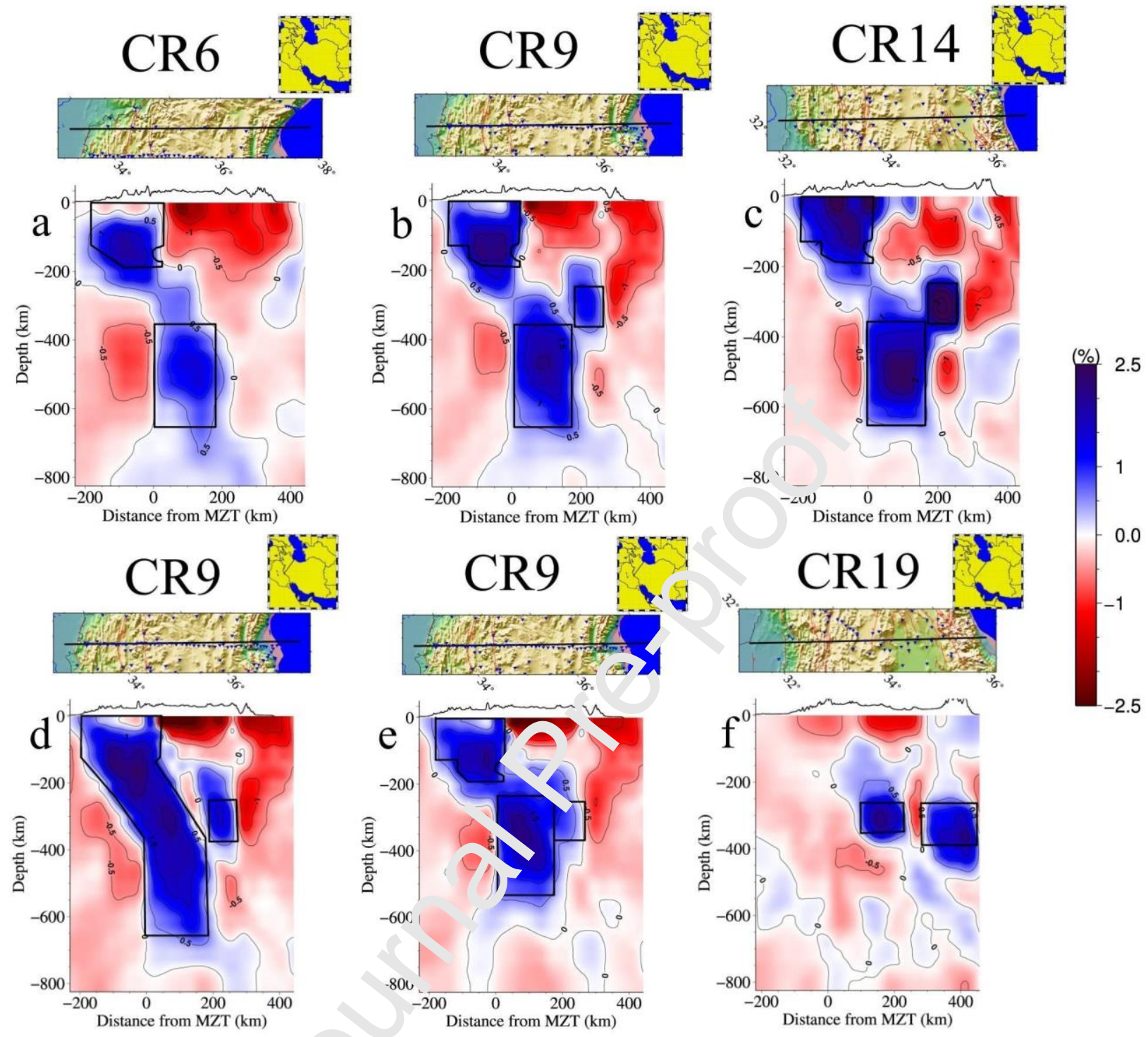

Figure 8. Simplified syntnetic tests to infer the robustness of the anomalies in NW Zagros. Cross sections $a, b$, and c represent a model with 150-km separation between AHL and TSH. Cross section d shows the synthetic model for a continuous slab. Cross section e illustrates a synthetic model with a 25-km separation between modelled ALH and TSH bodies and cross section $f$ shows two small high-velocity synthetic bodies with a horizontal separation of $100 \mathrm{~km}$, showing the resolving power of tomography where the CIH anomalies reside. 

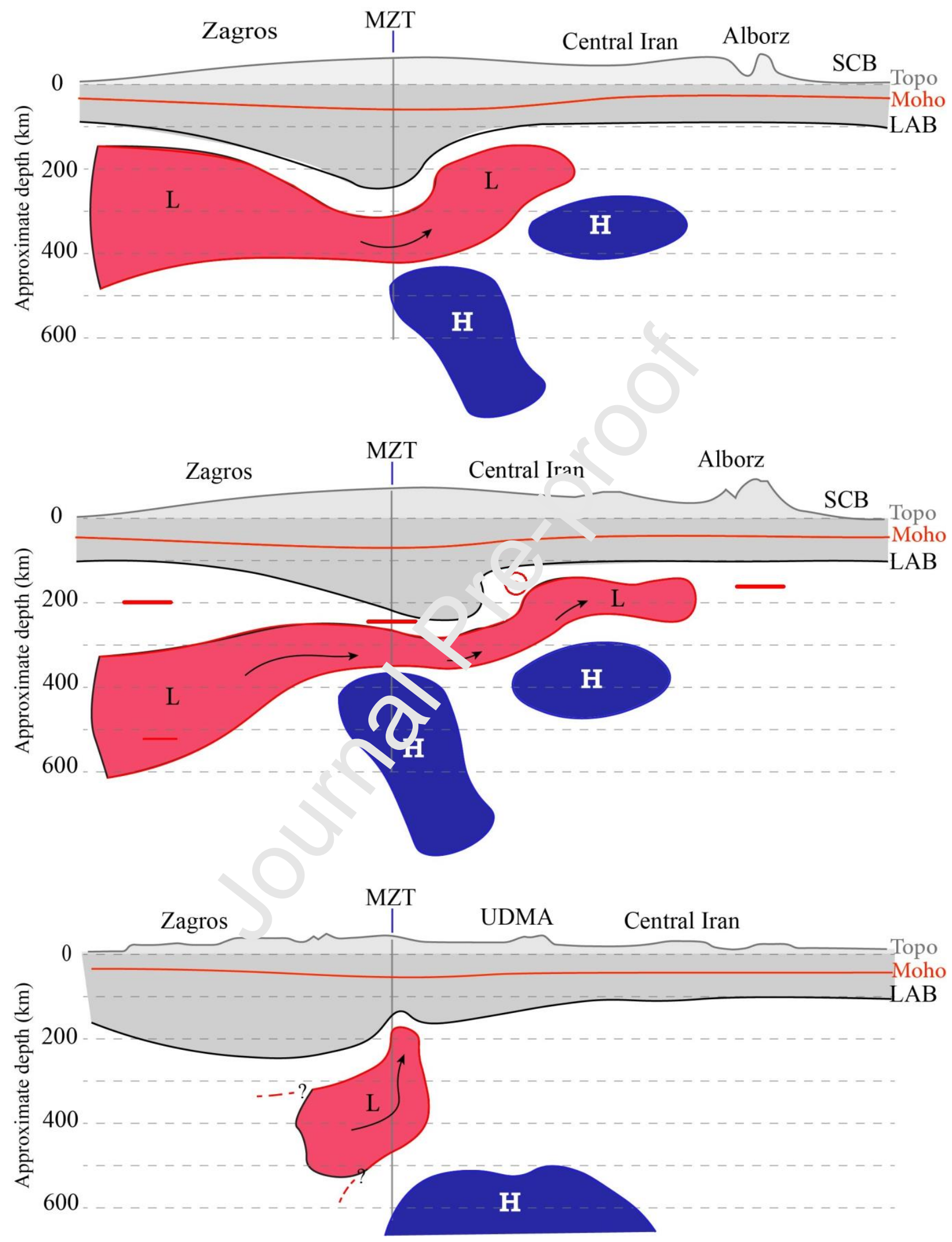
Figure 9. Three schematic cross-sections of the upper mantle beneath the collision zone that illustrate our interpretation of the tomography results. Profiles from top to bottom roughly correspond to the locations of the CIGSIP, Zagros03, and Zagros01 arrays, respectively. The splitting fast axes (red bars and circle-and-dot) shown in the middle profile represent the overall pattern of anisotropy as derived from the recent investigations referenced in the text. The arrows show the possible direction of the mantle flow field taking into account our tomographic interpretations, as well as inferences from seismic anisotropy. 


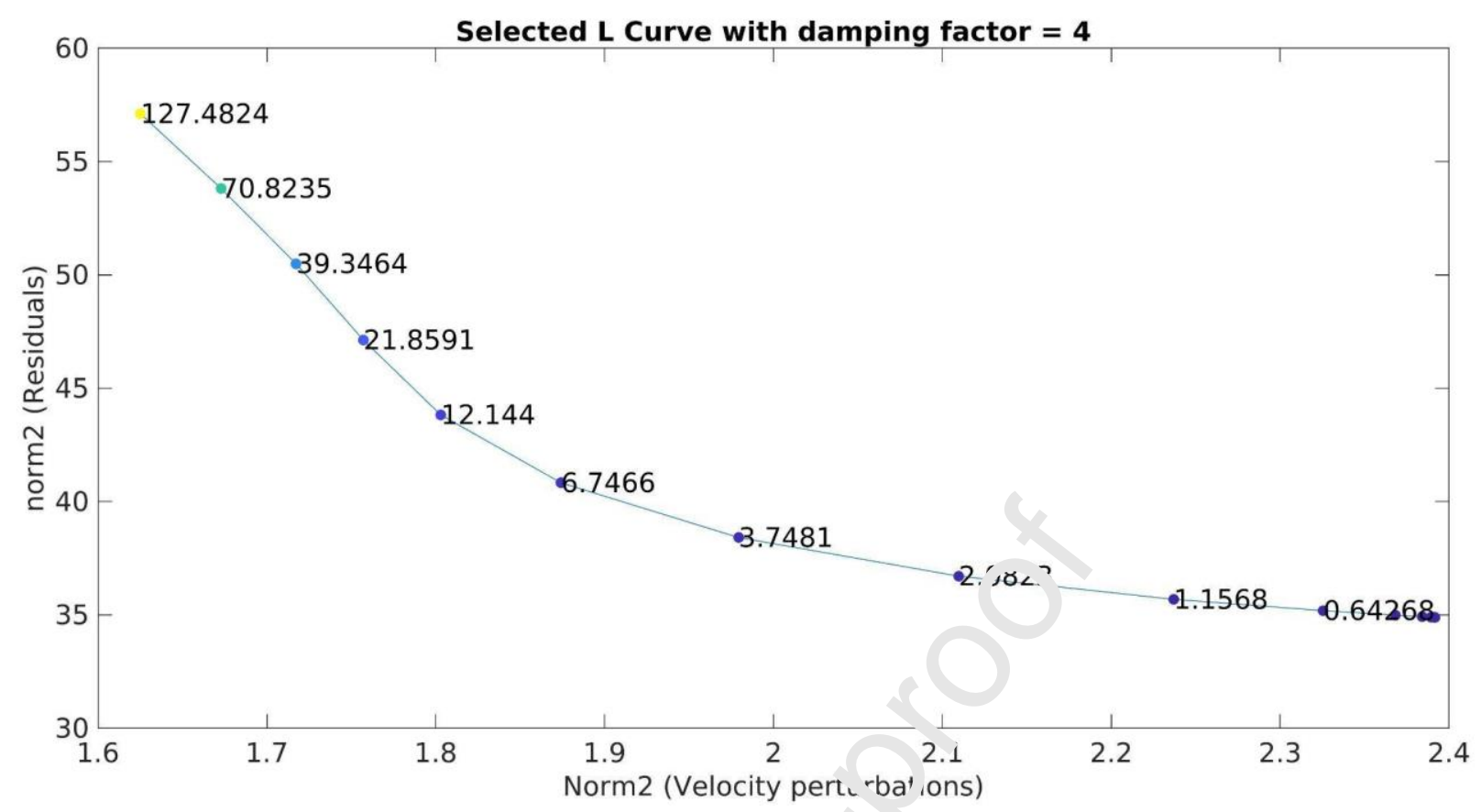

Figure S1. A selected L-Curve for evaluating the an ${ }^{m}$,ing and smoothing factors. This curve was calculated for damping factor $=4$, The values of ne smoothing factor are shown on the curve. Based on this diagram, we chose a best smoothing fac $\urcorner r$ of 12.144. 

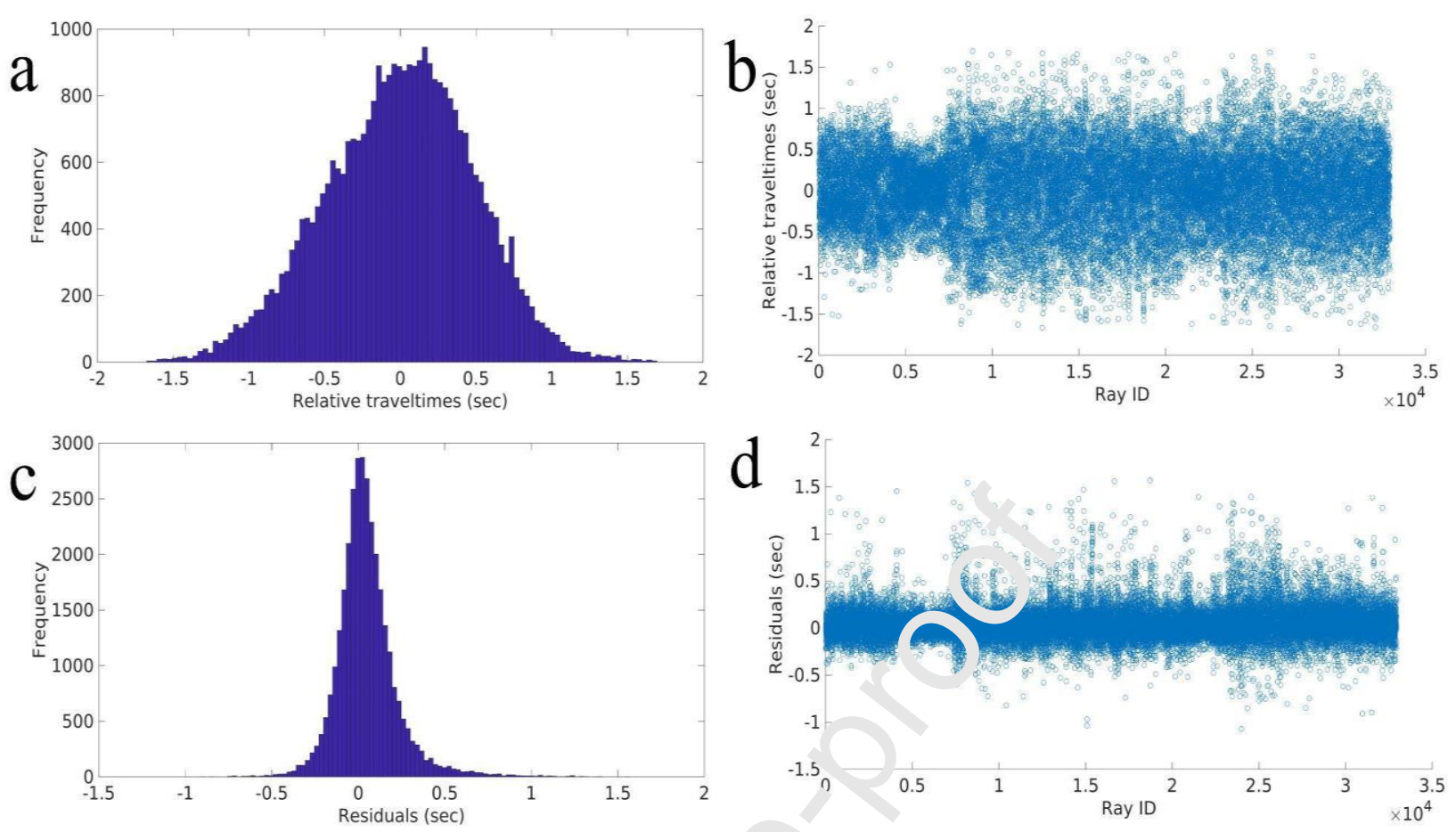

Figure S2. Histogram and scatter plot of rel..' ravel times before ( $a$ and $b)$ and after ( $c$ and $d)$ inversion. 
Mohammad Veisi: Conceptualization, Methodology, Software, Formal analysis, Data Curation, Writing, Validation. Farhad Sobouti: Supervision, Conceptualization, Methodology, Resources, Writing, Funding acquisition. Sébastien Chevrot: Conceptualization, Methodology, Software, Resources, Writing, Funding acquisition. Madjid Abbasi: Methodology, Supervision. Esmaeil Shabanian: Conceptualization, Writing. 


\section{Declaration of interests}

$\bigotimes$ The authors declare that they have no known competing financial interests or personal relationships

that could have appeared to influence the work reported in this paper.

$\square$ The authors declare the following financial interests/personal relationships which may be considered

as potential competing interests: 


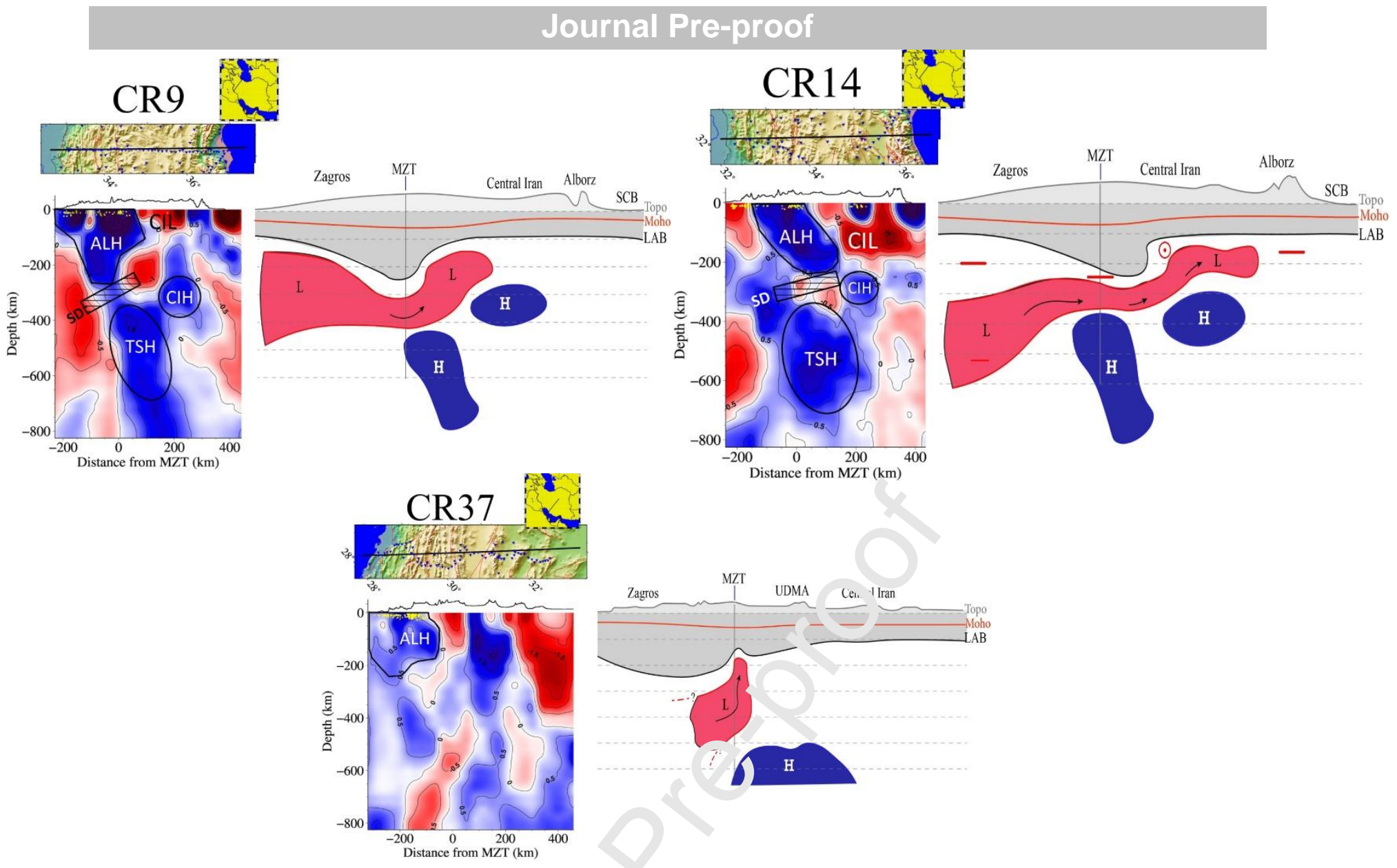

Three vertical cross sections and their schematic cross-sections $r$ nresenting our main finding. The major velocity anomalies are outlined: ALH (Arabian lithosphere High), CIL (central Iran Low), CIH (Central Iran Hir.., nd . SH (Tethyan Slab High). The hatched rectangle SD denotes the detachment of the subducted slab, red bars and circle and dot represent the spli w. fa ixis.

We map the lateral variations of P-wave velociv $\iota$ neath the Zagros collision zone in Iran down to $800 \mathrm{~km}$ depth by regional travel time tomography. Our tomographic study documents $v$. ria ions of lithospheric thickness between the Zagros and central Iran and a post-collisional slab detachment around $250 \mathrm{~km}$ depth. If we . su. nat the detachment occurred right beneath the base of the subducted Arabian continental margin, then the maximum thickness of the contir ${ }^{-}$.al root must be no greater than $225 \mathrm{~km}$. This would imply a doubling of the Zagros lithosphere as a result of collision. The absence of high-velocity anomalies far north from the MZT at the lithospheric depth range indicates that the lithosphere thickening has not propagated into the interior of central Iran. The high-velocity anomalies at 200-300 km depth beneath central Iran suggest the presence of fragments of delaminated mantle lithosphere. They also suggest post-collisional slab break-off in central Zagros that seems to be at an earlier stage in NW Zagros compared to central Zagros. From the shallow depth of the top of the detached slab, we infer that the break-off is recent (5-10 Ma), in good agreement with geological records. Effective detachment of an oceanic slab from continental lithosphere is often followed by the upwelling of the asthenosphere through slab windows, eduction, slab retreat, and eventually volcanism and exhumation of ultra-high-pressure rocks, which are not currently observed in central Iran. On the other hand, lack of deep seismicity, especially deep extensional events in the Zagros, indicates that the subducted slab does not exert gravitational pull on the base of the continental plate to reconcile these apparently contradictory observations, we propose that slab break-off in NW Zagros is very young. 
Highlights

- Upper mantle structure of the Zagros collision zone via teleseismic tomography.

- Evidence for a thicker lithosphere beneath the Zagros versus thinner lithosphere in the surrounding regions.

- Slab detachment near the base of the thickened Zagros lithosphere.

- Seismological evidence for mantle lithospheric delamination beneath central Iran. 